\title{
ORIGINAL ARTICLE Effect of glycogen synthase kinase-3 inactivation on mouse mammary gland development and oncogenesis
}

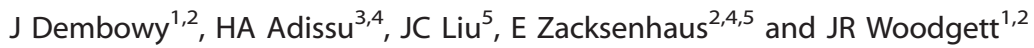

\begin{abstract}
Many components of the Wnt/ $\beta$-catenin signaling pathway have critical functions in mammary gland development and tumor formation, yet the contribution of glycogen synthase kinase-3 (GSK-3a and GSK-3 $\beta$ ) to mammopoiesis and oncogenesis is unclear. Here, we report that WAP-Cre-mediated deletion of GSK-3 in the mammary epithelium results in activation of Wnt/ $\beta$-catenin signaling and induces mammary intraepithelial neoplasia that progresses to squamous transdifferentiation and development of adenosquamous carcinomas at 6 months. To uncover possible $\beta$-catenin-independent activities of GSK-3, we generated mammaryspecific knockouts of GSK-3 and $\beta$-catenin. Squamous transdifferentiation of the mammary epithelium was largely attenuated, however, mammary epithelial cells lost the ability to form mammospheres suggesting perturbation of stem cell properties unrelated to loss of $\beta$-catenin alone. At 10 months, adenocarcinomas that developed in glands lacking GSK-3 and $\beta$-catenin displayed elevated levels of $\gamma$-catenin/plakoglobin as well as activation of the Hedgehog and Notch pathways. Collectively, these results establish the two isoforms of GSK-3 as essential integrators of multiple developmental signals that act to maintain normal mammary gland function and suppress tumorigenesis.
\end{abstract}

Oncogene (2015) 34, 3514-3526; doi:10.1038/onc.2014.279; published online 8 September 2014

\section{INTRODUCTION}

Epithelial malignancies, including those of the breast, are thought to initiate in stem-like cells defined by their capacity to self-renew and persist long enough to sustain and propagate mutations, as well as generate all functional cell types within a given tissue. These 'tumor-initiating cells' (TICs) may arise from normal adult stem cells as a consequence of alterations in the regulation of balance between self-renewal and differentiation or from more committed progenitors that have re-acquired stem cell characteristics during transformation. ${ }^{1,2}$ The contribution of distinct stem/progenitor cells to breast cancer heterogeneity remains obscure. With the identification of candidate mammary stem and progenitor populations that vary in their differentiation capacities, the nature of the TIC population and the impact of oncogenes within this critical cellular pool are being elucidated. ${ }^{1,3}$ Multiple lines of evidence have shown developmental pathways including Wnt, Hedgehog $(\mathrm{Hh})$ and Notch regulate stem cell homeostasis and have the capacity to induce cancer of various tissues when upregulated. The protein-serine kinases glycogen synthase kinase (GSK)-3 $a$ and $\beta$ are shared components of these networks and act to regulate signals emanating from receptors upon morphogen or ligand ligation. Inhibition of GSK-3 is critical to canonical Wnt signaling leading to increased $\beta$-catenin levels associated with elevated proliferation and suppression of differentiation in a number of tissues. ${ }^{4-7}$ GSK-3 has been shown to interact with $\mathrm{Hh}$ pathway components at several levels to inhibit transcriptional functions of Gli proteins. ${ }^{8-11}$ Several cell line studies have demonstrated that GSK-3 inhibition also modulates Notch signaling, at least in part by phosphorylating the Notch intracellular domain (NICD), thereby preventing nuclear entry and efficient association with its target gene promoters. ${ }^{12-14}$

Pathological hyperactivation of each of these pathways is a hallmark of many tumors, including breast cancer. Although mutations in $\beta$-catenin and other pathway components, such as adenomatous polyposis coli, are some of the most frequent signaling abnormalities contributing to human tumor pathogenesis, they are much less frequent in breast cancer. Despite the rarity of mutations, increased cytoplasmic and nuclear $\beta$-catenin levels have been documented in $\sim 40 \%$ of primary breast cancers including metaplastic breast carcinomas, a rare yet aggressive subset of breast cancer that shares features of both basal-like and triple-negative breast cancers. ${ }^{15-20}$ The mechanism by which Wnt/ $\beta$-catenin signaling is activated in these tumors is unknown but may involve excess Wnt ligand production and aberrant receptor activation. ${ }^{21-23} \mathrm{Wnt} / \beta$-catenin functions as a stem cell survival factor in continuously self-renewing systems including mammary tissues. ${ }^{24,25}$ Non-neoplastic glands of MMTV-Wnt1 and those from $\beta$-catenin mutant mice where the transgene lacks the $\mathrm{N}$-terminal region containing GSK-3 regulatory sites present an expanded progenitor cell fraction and limited or impaired capacity for functional differentiation in favor of a less committed cellular state. $^{26,27}$ In addition, Wnt/ $\beta$-catenin-responsive cells have recently been shown to be long-lived stem cells that make up a large proportion of the basal compartment able to survive multiple rounds of lobuloalveolar tissue turnover. ${ }^{28}$ This pool of vulnerable cells may constitute a vulnerable population for oncogenic mutation leading to generation of TICs. Indeed, stabilization of a $\beta$-catenin transgene expressed from its endogenous promoter or via adenomatous polyposis coli

${ }^{1}$ Lunenfeld-Tanenbaum Research Institute, Mount Sinai Hospital, Toronto, Ontario, Canada; ${ }^{2}$ Department of Medical Biophysics, University of Toronto, Toronto, Ontario, Canada; ${ }^{3}$ Pathology Core, Centre for Modelling Human Disease, Toronto Centre for Phenogenomics, Toronto, Ontario, Canada; ${ }^{4}$ Toronto General Hospital Research Institute, Toronto, Ontario, Canada and ${ }^{5}$ Department of Laboratory Medicine \& Pathobiology, University of Toronto, Toronto, Ontario, Canada. Correspondence: Dr JR Woodgett, Mount Sinai Hospital, Room 982, 600 University Avenue, Toronto, Ontario, M5G 1×5, Canada. 
mutations or deficiency leads to mammary hyperplasias, accompanied by loss of alveolar structures, ${ }^{29-32}$ whereas overexpression of $\mathrm{N}$-terminally truncated $\beta$-catenin results not only in precocious alveolar differentiation but also in formation of mammary adenocarcinomas. ${ }^{33-35}$ In addition, overexpression of the positive $\mathrm{Wnt} / \beta$-catenin regulator, casein kinase 2 , as well as a putative $\mathrm{Wnt} / \beta$-catenin target gene, cyclin D1, in the mammary epithelium results in hyperplasias, squamous differentiation and adenocarcinomas. $^{36,37}$

High levels of Notch- 1 were found to be associated with a poorer outcome in breast cancer patients while rearrangements of Notch-1 and 2 were found in triple-negative breast cancers where the fusion transcripts retained exons that encode the NICD thus maintaining transcriptional outputs. ${ }^{38-40}$ Increased numbers of breast stem/progenitor cells have been reported upon enhanced Notch signaling. ${ }^{41-43}$ This expansion of immature cells was predictive of tumor formation suggesting NICD1 expression in the mammary epithelium generates a population of unstable, pre-malignant progenitor cells. ${ }^{43}$ Notch activity has also been shown to result in luminal progenitor expansion leading to hyperplasia and tumorigenesis. ${ }^{41,44,45}$ Recently, two Notch-2 progenitor populations were identified within the luminal compartment representing unique mammary lineages. ${ }^{46}$ Thus, dysregulation of Notch activity may amplify a distinct stem/ progenitor population within the mammary tissues, which may contribute to TIC formation.
Hh ligand overexpression is associated with the basal-like breast cancer subtype and poor outcome in terms of metastasis and breast cancer-related death while expression of Hh receptor Ptch1 and transcriptional activator Gli1 has been detected in invasive carcinomas but not in normal breast epithelium. ${ }^{47-51}$ Hh may increase the proliferative capacity and enhance self-renewal of mammary progenitors rather than enlarge the multi-potent stem cell pool, thus perturbing the stem cell vs progenitor cell balance. ${ }^{52-55}$ In concordance, Gli1 overexpression within the mammary epithelium induces mammary tumors with increased levels of Bmi-1, a transcriptional repressor of the polycomb gene family previously implicated in stem cell maintenance. ${ }^{56,57}$

To assess the functional consequence of GSK-3 loss from the mammary epithelium and to explore potential $\beta$-cateninindependent roles of these protein kinases, both GSK-3 genes were deleted specifically in mammary tissues in the presence or absence of a functional $\beta$-catenin gene. Glands of GSK-3 mutant animals assumed epidermal identity via cell-autonomous mechanisms leading to adenosquamous carcinoma formation. Although mammary-selective inactivation of $\beta$-catenin initially subverted epidermoid transdifferentiation of GSK-3-null tissue, misregulation of $\mathrm{Hh}$ and Notch pathways contributed to the development of adenocarcinomas in the absence of GSK-3 and $\beta$-catenin. Thus, GSK-3, by restraining multiple pathways maintains mammary epithelial cell (MEC) function and inhibits tumor formation.
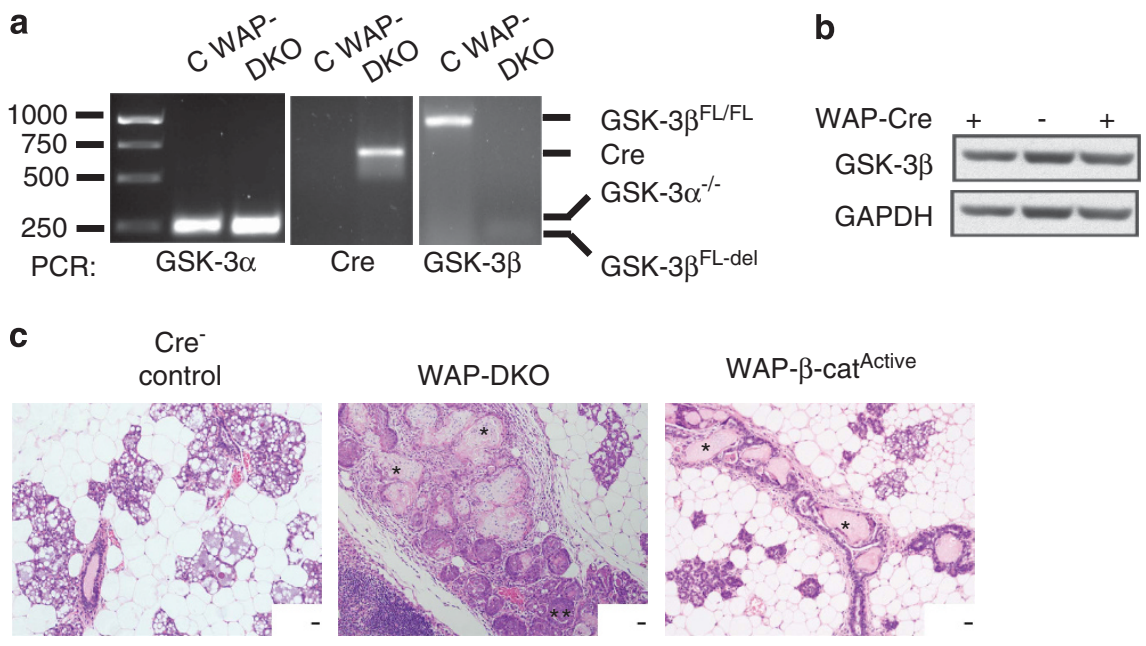

d

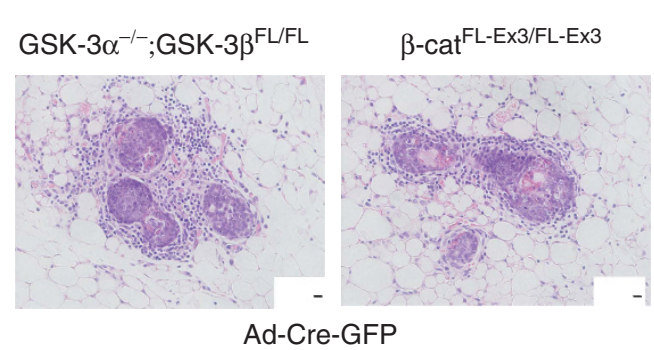

Figure 1. Loss of GSK-3 in the mammary epithelium results in MIN and squamous transdifferentiation. (a) Mid-pregnant glands were isolated from either GSK-3 $\alpha^{-1-}$; GSK-3 $\beta^{\mathrm{FL} / \mathrm{FL}}$ (control, c) or WAP-Cre; GSK-3 $\alpha^{-1-}$; GSK-3 $\beta^{\mathrm{FL} / \mathrm{FL}}$ (WAP-DKO) mice and were PCR-analyzed using primers specific for the detection of floxed (850 bp) and deleted (250 bp) alleles of GSK-3 $\beta$, Cre (750 bp) or GSK-3 $\alpha$ ( $250 \mathrm{bp}$ ) confirming GSK-3 $\alpha$-null status and excision at the GSK-3 $\beta$ locus. (b) Representative immunoblot of WAP-DKO whole gland lysates probed with indicated antibodies indicating depletion of GSK-3 $\beta$ protein in two Cre positive animals. GAPDH was used as a loading control. (c) Hematoxylin and eosin staining of glands removed from control, WAP-DKO $(n=14)$ or WAP- $\beta$-catenin Active $(n=6)$ mice as indicated. The degree of transdifferentiation varied across glands; shown are representative images. *Denotes ghost cells; a region of MIN is denoted by ** in the middle panel. (d) Mammary gland outgrowth produced by injection of dissociated control (Ad-GFP), GSK-3-ablated or $\beta$-catenin-stabilized (Ad-Cre-GFP) MECs into a cleared fat pad. Squamous foci were observed in $2 / 3$ DKO and $3 / 3 \beta$-catenin ${ }^{A c t i v e}$ MEC-transplanted glands indicating these effects are cell-autonomous and intrinsic to the mammary epithelium. 


\section{RESULTS}

Generation of mice harboring mammary-gland-selective deletion of GSK-3 $\alpha$ and GSK-3 $\beta$

To investigate the functions of GSK-3s in the mammary gland, we generated GSK-3 $a^{-1-}$; GSK-3 $\beta^{\text {Exon2 LoxP/Exon2 LoxP }}$, referred to as GSK- $3 a^{-/-} ; \mathrm{GSK}-3 \beta^{\mathrm{FL} / \mathrm{FL}}$ mice with mammary-gland-selective deletion of the floxed GSK-3 $\beta$ alleles achieved by Cre-mediated recombination driven by the whey acidic protein (WAP) promoter yielding WAP-GSK-3 double knockout animals (WAP-DKO). Expression of the WAP-Cre transgene can be detected during the estrus stage of the murine estrus cycle (hence starting at $\sim 4$ weeks of age) and the WAP promoter is substantially increased during each pregnancy when WAP expression is observed in both ductal and alveolar epithelial cells, particularly starting from 15 days post coitum (dpc 15). ${ }^{58-60}$

Genomic PCR of WAP-DKO pregnant glands confirmed absence of GSK-3 $a$ and loss of GSK-3 $\beta$ (Figure 1a). Cre expression was found in a large proportion of WAP-DKO cells as assessed by immunohistochemistry (IHC) (Figure 2). Immunoblotting of pregnant WAP-DKO whole-gland lysates demonstrated excision of the GSK-3 $\beta^{\mathrm{FL} / \mathrm{FL}}$ allele (Figure $1 \mathrm{~b}$ ). Unrecombined GSK-3 $\beta$ present in the non-epithelial, stromal compartment (e.g., fat, extracellular matrix, immune cells) of mammary tissues not targeted by WAP-Cre likely accounts for the observed residual GSK-3 $\beta$ protein.

$\beta$-catenin is a major GSK-3 target implicated in multiple stages of mammary development as well as in oncogenesis. For direct comparison with GSK-3 DKO animals, we also generated mice with stabilized $\beta$-catenin, which have been characterized previously. ${ }^{31}$ In this case, endogenous $\beta$-catenin was activated in mammary tissues by WAP-Cre recombination of the floxed exon 3 allele of $\beta$-catenin ( $\beta$-catenin ${ }^{\text {Exon } 3 \text { LoxP/+ }}$, referred to as $\beta$-catenin ${ }^{\mathrm{FL}-\mathrm{Ex} 3 /+}$ ) that encodes for the portion of the amino-terminus containing GSK-3 regulatory phosphodegron sites, thus termed WAP- $\beta$ catenin ${ }^{\text {Active }}$.

WAP-Cre-mediated inactivation of GSK-3 in the murine mammary epithelium results in squamous transdifferentiation

Approximately $81 \%$ of primiparous midpregnant (dpc 15) WAP-DKO glands exhibited pronounced epidermoid transdifferentiation (Table 1, Figure 1c), similar to that found in WAP- $\beta$ -

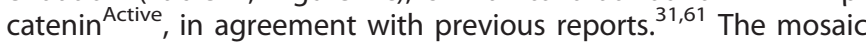
distribution of WAP-Cre, reflecting the heterogeneity in the synthetic activities of cells within individual alveoli during estrous and at midpregnancy, likely accounts for the variability in the phenotypes observed and also strongly suggests these effects are cell autonomous. Mammary intraepithelial neoplasia (MIN) was a predominant feature of WAP-DKO glands where lumens of alveoli were filled with atypical cells in a solid pattern. Multilayered structures exhibiting squamous differentiation with central ghost cells (large masses of 'shadow' cells or cellular ghosts lacking nuclear and cytoplasmic details with clear conservation of basic cellular outline) and keratinization were also frequently observed and appeared to arise from within MIN lesions (Figure 1c). In contrast, MIN was rare in WAP- $\beta$-catenin ${ }^{\text {Active }}$ glands, which were found to contain squamous differentiation as well as prominent keratinization with many of the larger lesions completely replaced by ghost cells (Figure 1c). Whereas lesions in dpc 15 WAP-DKO glands appeared to arise from both the alveolar and ductal secretory epithelium, ducts seemed to be preferentially affected in WAP- $\beta$-catenin ${ }^{\text {Active }}$ (Figure 1c). Unsurprisingly, the transdifferentiated glands of WAP-DKO and WAP- $\beta$-catenin ${ }^{\text {Active }}$ females were unable to support nourishment of pups and litters were found dead within $24 \mathrm{~h}$ of birth with no evidence of milk spots.

To examine the nature of effects of GSK-3 deletion on mammary gland development, we enriched for primary mouse MECs from GSK-3a ${ }^{-/-}$; GSK-3 $\beta^{\text {FL/FL }}$ mice and infected them with adenovirus expressing Cre-GFP (Ad-Cre-GFP) or GFP alone (Ad-GFP) as a control. We then introduced paired groups of $\mathrm{KO}$ and control MECs into the contralateral cleared mammary fat pads of 3-week-old FVB mice and allowed them to develop for a period of 8 weeks. After infection with Ad-GFP, floxed MECs generated normal mammary epithelial outgrowths upon transplantation (Figure 1d). In contrast, after infection with Ad-Cre-GFP, squamous foci were once again observed in fat pads transplanted with GSK-3 KO MECs (Figure 1d). Similarly, epidermoid transdifferentiation was also found in outgrowths from $\beta$-catenin ${ }^{\text {Active }}$ MECs following injection of Ad-Cre-GFP-infected $\beta$-catenin ${ }^{\mathrm{FL}-\mathrm{E} \times 3 /+}$ MECs (Figure 1d). These data provide evidence that effects of mammary tissue-specific ablation of GSK-3 are intrinsic to the mammary epithelium.

Activation of $\mathrm{Wnt} / \beta$-catenin signaling in mammary glands lacking GSK-3

More detailed analysis revealed a correlation between the level of $\beta$-catenin expression and changes in cell morphology in WAP-DKOs and in WAP- $\beta$-catenin ${ }^{\text {Active }}$ (Figure 2 ), as $\beta$-catenin was primarily found surrounding keratinized structures. Nuclear $\beta$-catenin was never observed in control (GSK-3a $a^{-/-} ; \mathrm{GSK}-3 \beta^{\mathrm{FL} / \mathrm{FL}}$ ) virgin glands in which it is normally maintained at a low level and is localized primarily at the membrane (Figure 2). As assessed by increased BrdU incorporation and Ki67 staining, dpc 15 WAP-DKO glands were actively proliferating (Figure 2), beyond the level associated with normal mammary growth during pregnancy. Variable expression of cytokeratin 8/18 (K8/18) and cytokeratin 14, markers of luminal and myoepithelial lineages, respectively, was maintained within the MIN lesions (Figure 2). Keratinizing epithelium of both WAP-DKO and WAP- $\beta$-catenin ${ }^{\text {Active }}$ was associated with intense expression of cytokeratin 6 (K6) (Figure 2), which was never observed in control glands. On the basis of its expression pattern, which is observed early in embryonic mammary development and in non-proliferating terminal end buds but rare in mature glands, $\mathrm{K} 6$ is considered a putative progenitor marker in the mammary epithelium. ${ }^{27,62,63}$ However, because K6 is also found in activated keratinocytes in the epidermis, ${ }^{63}$ it is difficult to discern whether the observed elevation of K6 in WAP-DKO and WAP- $\beta$-catenin ${ }^{\text {Active }}$ represents an expansion of immature cells or is a consequence of epidermoid transdifferentiation. Flow cytometric analysis of MECs purified from dpc 15 glands of both strains using CD24 and CD49f mammary stem cell markers did not reveal abnormalities in the stem cell profile where the ratios of luminal $\left(C D 24^{\text {hi }}: C D_{4} 4 f^{+}\right)$to basal $\left(C D 24^{\text {lo }}: C D 49 f^{h i}\right)$ cells were similar to control glands (data not shown). This result is consistent with positive K6 staining reflecting a switch to epidermoid marker expression in transdifferentiated cells rather than aberrations within the mammary stem cell compartment. These observations correlate $\beta$-catenin stabilization with proliferation, neoplastic lesion formation and alterations in the differentiation status of the mammary epithelium. Taken together, these results show that the two GSK-3 isoforms, by restraining $\beta$-catenin levels and ensuing proliferation, play a key role in maintaining glandular cell fate in the mammary epithelium.

Loss of GSK-3 and activation of $\beta$-catenin have differential effects on mammary stem cells

To further investigate GSK-3 functions, we employed a mammosphere (MS) assay to measure in vitro stem/progenitor cell frequency in primary MEC preparations. ${ }^{64}$ In the absence of attachment to an exogenous substratum or cell-cell adhesion, stem cells are able to survive and proliferate and we found no significant differences in primary or secondary MS formation of GSK-3 DKO MECs generated by infecting $\mathrm{Lin}^{-} \mathrm{GSK}-3 \mathrm{a}^{-1-}$; GSK-3 $\beta^{\mathrm{FL} / \mathrm{FL}}$ cells with either Ad-GFP or Ad-Cre-GFP. Interestingly, 

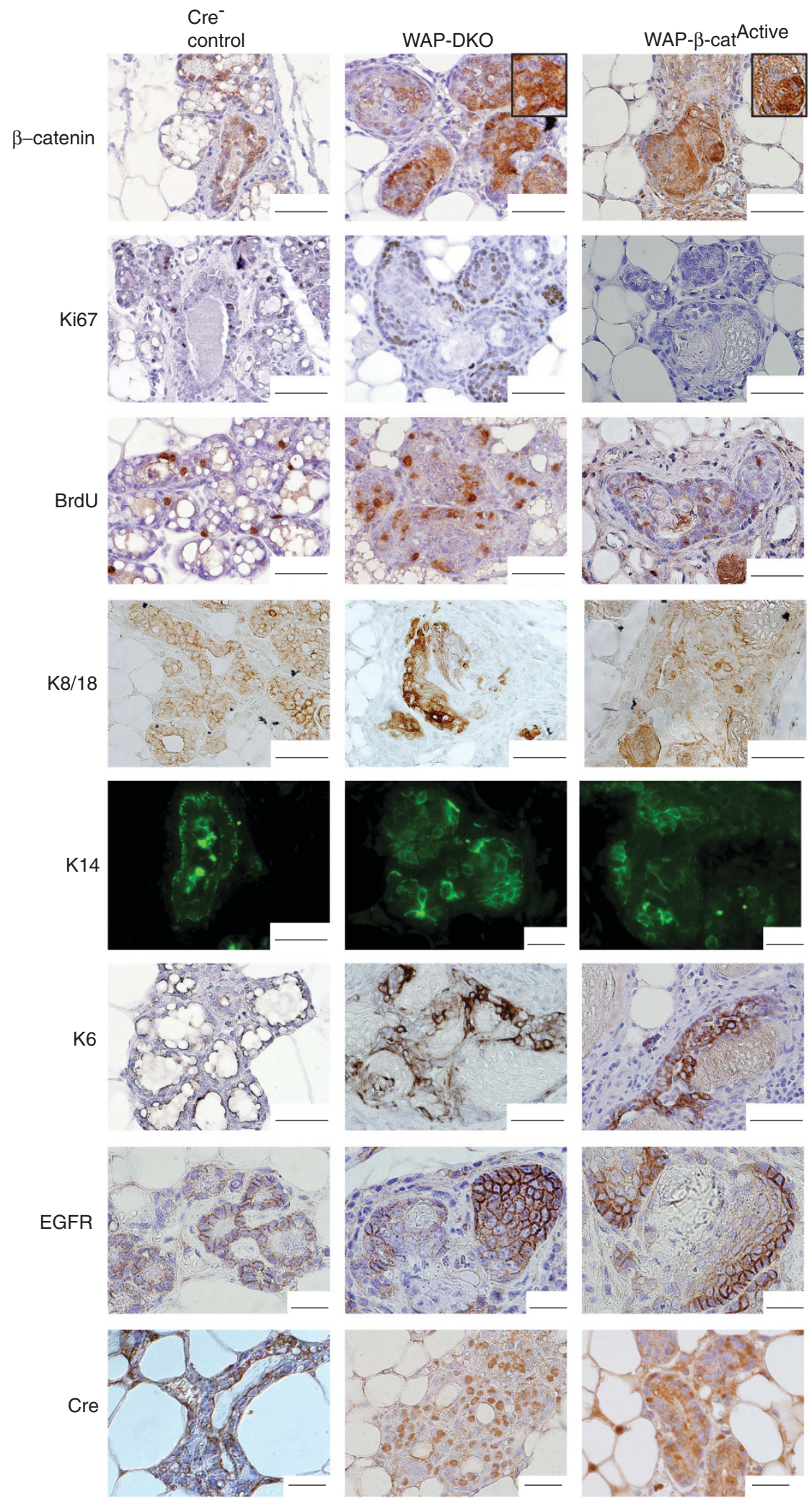

Figure 2. Comparison of mammary glands from WAP-DKO and WAP- $\beta$-catenin ${ }^{\text {Active }}$ mid-pregnant animals. Representative immunostained sections of glands removed from primiparous animals of indicated genotypes at dpc 15 . Tissues were probed with antibodies to identify cells bearing mammary lineage markers (luminal K8/18, myoepithelial K14), keratin 6 (K6, see text) and to assess proliferation (BrdU, Ki67) and levels of $\beta$-catenin, EGFR and Cre. Similar staining patterns across this marker panel were observed in both WAP-DKO and WAP- $\beta$-catenin Active pregnant glands with strong nuclear and cytoplasmic $\beta$-catenin (insets) and high proliferation as well as presence of both luminal and myoepithelial cells that also strongly express EGFR. Cre expression varied across glands and representative images are shown. Total number of

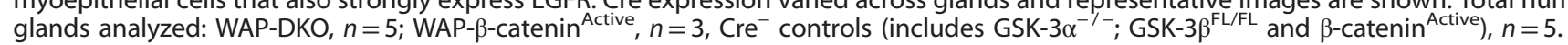


Table 1. Spectrum of phenotypes observed in females across examined models.

\begin{tabular}{lcrr}
\hline Stage & Dpc 15 & \multicolumn{2}{c}{ Multiparous } \\
\hline Genotype & $\begin{array}{c}\text { Incidence of } \\
\text { transdifferentiation }\end{array}$ & $\begin{array}{r}\text { Median tumor } \\
\text { latency (days) }\end{array}$ & Metastasis \\
\hline WAP-DKO & $75 \%(n=12)$ & $180.5(n=18)$ & $0(n=10)$ \\
WAP-TKO & $40 \%(n=25)^{\mathrm{a}}$ & $300(n=27)$ & $0(n=13)$ \\
WAP- $\beta$-cat Active & $100 \%(n=3)$ & $211(n=10)$ & $11 \%(n=18)$ \\
3/4 WAP-DKO & NA & $429(n=4)$ & $0(n=3)$ \\
\hline
\end{tabular}

Abbreviations: $d p c$, days post coitum; WAP-DKO, whey acidic protein-double knockout; WAP-TKO, whey acidic protein-triple knockout. ${ }^{2}$ Basal background level of very mild single foci also observed in some $\mathrm{Cre}^{-}$controls.

whereas the CD24:CD49f marker profile of MS dissociated on day 12 post infection was not significantly changed upon loss of GSK-3 across replicate experiments (Figures $3 \mathrm{~b}$ and $\mathrm{c}$ ), a prominent $\mathrm{CD} 24^{\mathrm{hi}}: \mathrm{CD} 49 \mathrm{f}^{\mathrm{lo} /-}$ population was observed upon stabilization of $\beta$-catenin (Figures $3 a$ and $c$ ). To further investigate the functional relevance of these populations, $\beta$-catenin ${ }^{\text {Active }}$ MECs were sorted into CD24 $4^{\mathrm{hi}}: \mathrm{CD} 49 \mathrm{f}^{\mathrm{lo} /-}$ and $\mathrm{CD} 24^{\mathrm{lo} /-}: \mathrm{CD}_{49 f^{\mathrm{hi}}}$ fractions with only $\mathrm{CD} 24^{\mathrm{lo} /-}: \mathrm{CD}_{49 \mathrm{f}^{\mathrm{hi}}}$ cells capable of forming secondary MS, although CD24 $4^{\mathrm{hi}}: \mathrm{CD} 49 \mathrm{f}^{\mathrm{fo} /-}$ MEC population was regenerated (data not shown). On the basis of these in vitro data, we conclude that, unlike direct stabilization of $\beta$-catenin, GSK-3 loss does not significantly impact the mammary gland stem cell compartment.

\section{Mammary tumors develop in absence of GSK-3}

Following a median 6-7 months of continuous breeding, all WAP-DKO and WAP- $\beta$-catenin ${ }^{\text {Active }}$, but not control female mice, developed large-sized mammary ductal adenocarcinomas with atypical squamous transdifferentiation (Table 1, Figure 4c). There was no statistical difference in survival curves for these strains $(P=0.2333$ log-rank test, $P=0.3706$ Wilcoxon test) (Figure $4 c)$. Near-complete loss of GSK-3 $\beta$ in WAP-DKO tumors was confirmed by detection of markedly elevated $\beta$-catenin levels by immunoblotting (Figure 4a).

The primary tumors in WAP-DKO and WAP- $\beta$-catenin ${ }^{\text {Active }}$ were composed of poorly differentiated glandular structures of variable size and large numbers of multilayered squamous epithelial structures (Figure 4b). The neoplastic cells had a high nuclear-tocytoplasmic ratio (1:1), a moderate amount of granular basophilic cytoplasm and a round to oblong large nucleus with fine chromatin and one to three prominent nucleoli. There was marked anisocytosis (variation in cellular size) and anisokaryosis (variation in nuclear size). Occasional, large multinucleated cells were also present. Nearly half of the tumor volume was composed of multilayered epithelial structures with squamous differentiation and central ghost cells. Some of these structures contained lamellar keratin material and in rare areas, had features reminiscent of normal stratified, keratinized, squamous epithelium (epidermis). Invasion to the regional lymph node was observed occasionally in WAP-DKO and WAP- $\beta$-catenin ${ }^{\text {Active }}$ tumors (data not shown).

As expected, $\beta$-catenin was elevated specifically in WAP-DKO tumors as compared with adjacent normal mammary tissue (Figure 4a). Tumor expression of ducto-luminal (K8/18) and ductobasal (K14) cells was maintained along with K6 and EGFR (Figure 5). A high level of proliferation was evident in all tumors based on Ki67 staining (Figure 5).

We found $\sim 10 \%$ rate of pulmonary metastasis in WAP- $\beta$ catenin $^{\text {Active, }}$ whereas none of the WAP-DKO tumors were ever found to metastasize (Table 1). Further assessment of metastatic potential showed $\mathrm{Lin}^{-}$tumor cells from two of eight
WAP- $\beta$-catenin Active were able to regenerate tumors when injected into syngeneic recipients suggesting their weak malignant propensity (data not shown). In contrast, none of WAP-DKO Lin $^{-}$tumor cells grew following transplantation.

Tumor incidence was also noted in $20 \%$ of glands lacking three of the four GSK-3 genes, that is, of genotype WAP-Cre; GSK-3a ${ }^{-1-}$ GSK-3 $\beta^{\mathrm{FL} /+}$; or WAP-Cre; GSK-3a ${ }^{-/+}$; GSK-3$\beta^{\mathrm{FL} / \mathrm{FL}}$ (referred to as $3 / 4$ WAP-DKO) arising with a median latency of 14 months, which was statistically significantly different from WAP-DKO $(P=0.0015$ log-rank test, $P=0.0075$ Wilcoxon test) (Table 1, Figure $4 c$ ). No tumors were observed in animals with either just the a or $\beta$ isoform of GSK-3 missing. The markedly different morphology of $3 / 4$ WAP-DKO tumors (Figure $4 \mathrm{~b}$ ) and their low incidence may reflect these being spontaneous age-related tumors previously reported in the FVB strain rather than attributable to loss of GSK-3. This may also be true of the single observed case of tumor formation in virgin WAP-DKOs (latency 13.6 months). However, we cannot exclude the possibility that loss of three of the four alleles causes weak tumor predisposition.

From these data, we conclude that depletion of all four alleles of GSK-3 from the mouse mammary epithelium leads to rapid formation of adenosquamous carcinomas indicating GSK-3 functions to inhibit tumorigenesis within this compartment.

Loss of GSK-3 drives $\beta$-catenin-independent mammary tumorigenesis

To distinguish possible $\beta$-catenin-independent GSK-3-specific functions, mice harboring LoxP sites in introns 2 and 6 of $\beta$-catenin ( $\beta$-catenin Exon 2-6 LoxP/Exon 2-6 LoxP, referred to as $\beta$-catenin $\left.{ }^{\mathrm{FL}-\mathrm{E} \times 2-6 / \mathrm{FL}-\mathrm{E} \times 2-6}\right)$ were mated with WAP-DKOs to generate animals with mammary glands lacking both pairs of GSK-3 alleles as well as $\beta$-catenin (referred to as WAP-triple knockout, WAP-TKO) (Figures $6 a$ and b). Residual unrecombined alleles of GSK-3 $\beta$ and $\beta$-catenin in mid-pregnant WAP-TKOs mammary compartments lacking expression of WAP-Cre likely reflect presence of these proteins in whole gland lysates (Figure 6b). Strikingly, dpc 15 WAPDKO squamous transdifferentiation was rescued by the loss of $\beta$-catenin and no alterations in stem cell populations were observed as judged by the CD24:CD49f profile (data not shown). To determine whether simultaneous ablation of GSK-3 and $\beta$-catenin affected the propensity of MECs to form MSs, GSK-3a ${ }^{-1-} ; \quad$ GSK-3 $\beta^{\mathrm{FL} / \mathrm{FL}} ; \quad \beta$-catenin ${ }^{\mathrm{FL}-\mathrm{E} \times 2-6 / F L-E \times 2-6}$ MECs were infected with either Ad-Cre-GFP or Ad-GFP. Whereas MS formation was unaffected by Ad-GFP, no spheres were ever observed in TKO MECs (Figure 6c). Analysis of the CD24:CD49f stem cell profile of these TKO MECs did not reveal any aberrations (Figure $6 \mathrm{c}$ ). To evaluate the possibility that membrane/adhesion functions of $\beta$-catenin are necessary for sphere formation, we subjected $\beta$-catenin ${ }^{\mathrm{FL}-\mathrm{E} \times 2-6 / \mathrm{FL}-\mathrm{E} \times 2-6}$ MECs to the MS assay and found sphereforming ability was normal (data not shown). Thus, in this shortterm assay, loss of GSK-3 and $\beta$-catenin abrogates stem cell functionality without perturbation to the stem cell compartment.

After 10 months, multiparous WAP-TKO dams developed mammary tumors (Table 1, Figure 7a). This temporal incidence was statistically significantly different from both WAP-DKO and WAP- $\beta$-catenin ${ }^{\text {Active }}$ tumor latency $(P<0.0001$ log-rank and Wilcoxon tests) (Figure 7a). Unlike WAP-DKOs, which developed adenosquamous carcinomas with a prominent squamous component, acinar adenocarcinomas formed in WAP-TKOs with rare and multifocal squamous foci present in some tumors (Figure 7c). Both mammary lineage markers continued to be expressed in these tumors along with K6, SMA, EGFR and Ki67 (Figure 7e). GSK-3 $\beta$ expression was virtually undetectable in these tumors (Figure $7 \mathrm{~b}$ ) and laser-capture micro-dissection demonstrated efficient excision at the $\beta$-catenin locus in both the adeno and squamous components of tumors (data not shown). Interestingly, we found elevated levels of $\gamma$-catenin/plakoglobin (Figure $7 \mathrm{~b}$ ), an armadillo 

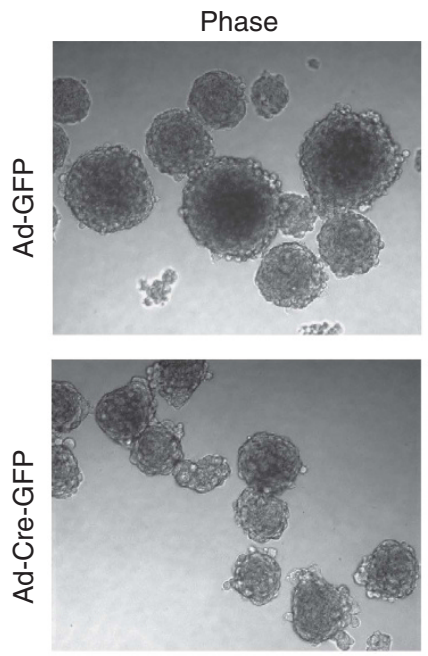

b
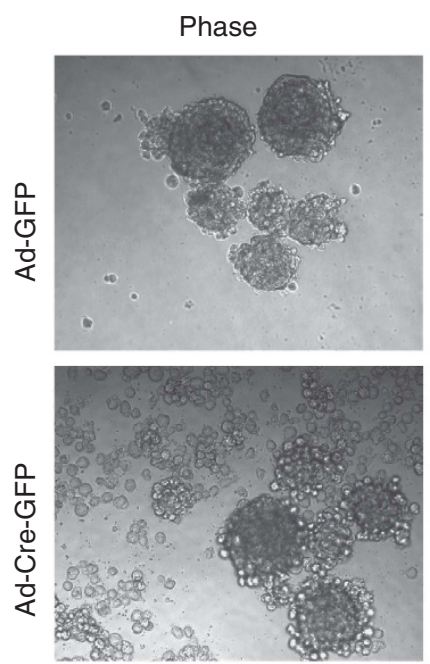

c

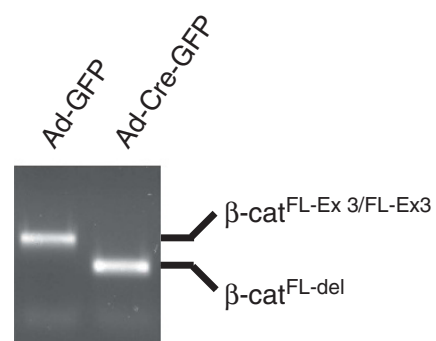

$\beta$-cat ${ }^{\mathrm{FL}-\mathrm{Ex} 3 / \mathrm{FL}-\mathrm{Ex} 3}$
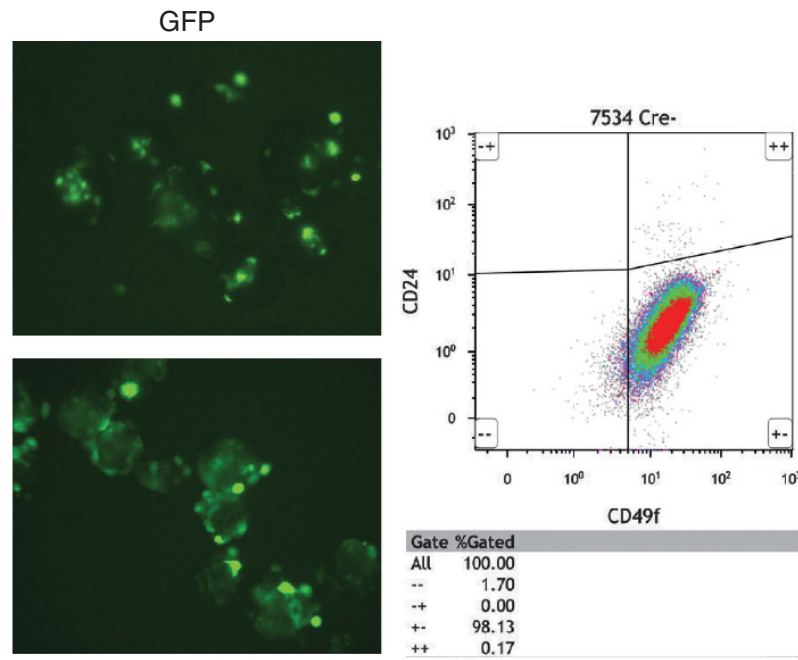

GSK-3 $\alpha^{-/-} ;$GSK-3 $\beta^{\text {FL/FL }}$
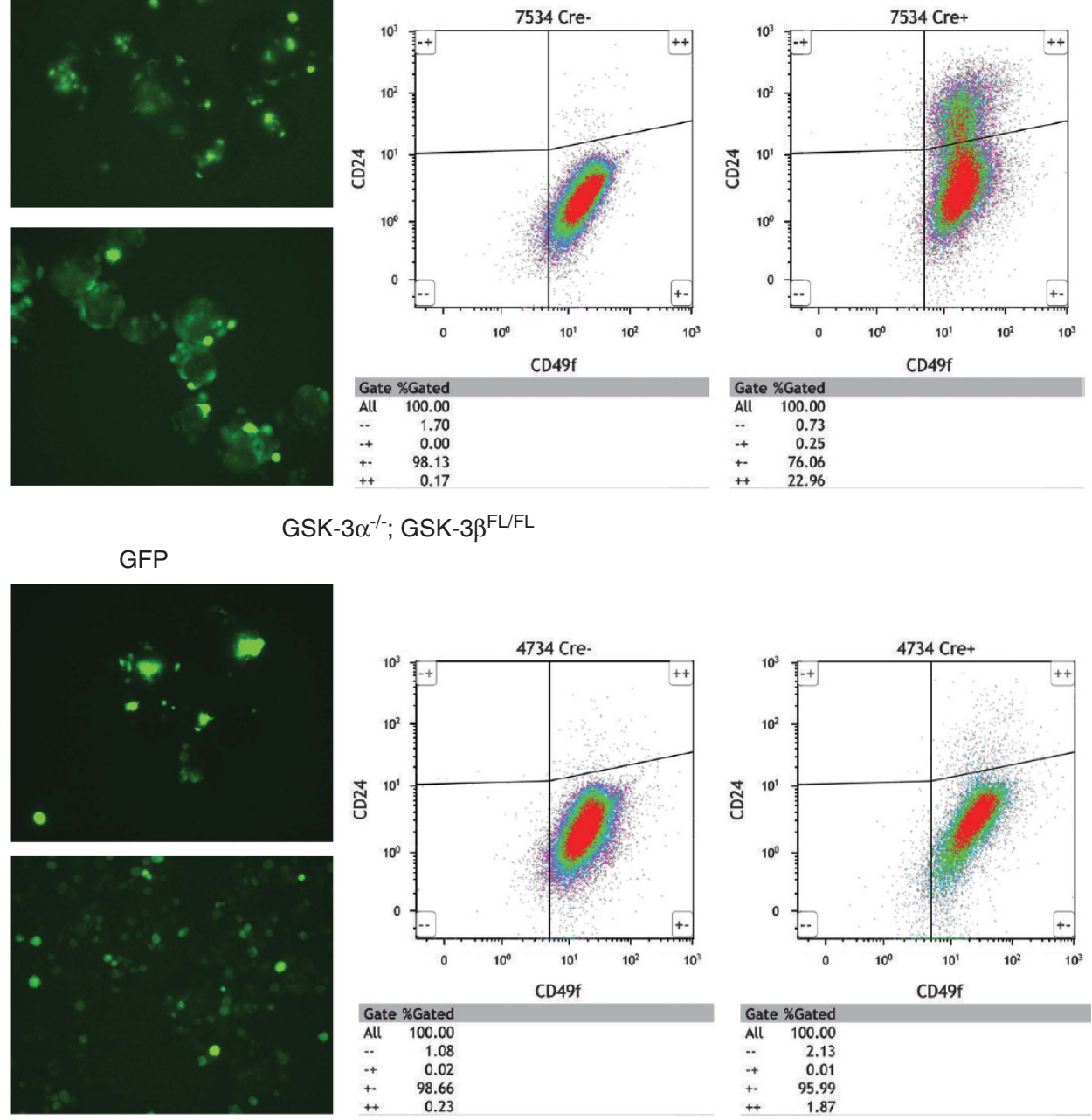

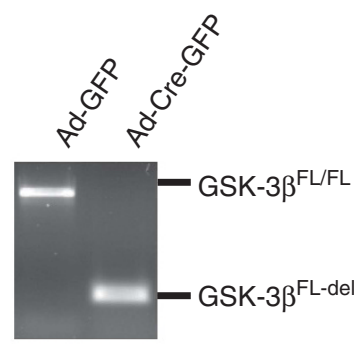

\section{GSK-3 $\alpha^{-/-}$;}

GSK-3 $\beta^{\mathrm{FL} / \mathrm{FL}}$

Figure 3. Mammosphere formation in MECs depleted of GSK-3 and $\beta$-catenin. $\beta$-catenin ${ }^{\text {Active }}$ (a) or GSK-3-ablated (b) MECs were cultured under conditions promoting MS formation and imaged on day 12 post infection. MS were then dissociated and analyzed by flow cytometry to assess the CD24:CD49f stem cell profile. Shown are representative of three separate experiments demonstrating efficient MS formation across all genotypes. A CD24 $4^{\text {hi }}:$ CD49f ${ }^{\text {lo/ }}$ population was consistently observed in $\beta$-catenin ${ }^{\text {Active }}$ MECs. (c) PCR genotyping of an aliquot of Ad-GFP or Ad-Cre-GFP MECs of indicated genotypes analyzed using primers specific for detection of floxed and deleted alleles of GSK-3 $\beta$ ( $850 \mathrm{bp}, 250 \mathrm{bp}$ ) and $\beta$-catenin ${ }^{\mathrm{FL}-\mathrm{Ex} 3 / \mathrm{FL}-\mathrm{Ex} 3}$ (650 bp, $400 \mathrm{bp}$ ) showing efficient Cre excision at both loci at day 12 post infection.

domain-containing $\beta$-catenin homologue that associates with both classic and desmosomal cadherins ${ }^{65}$ specifically in WAP-TKO tumors suggesting it may compensate for the loss of $\beta$-catenin functions, at least at the level of cell-cell adhesion. In addition to its role in the Wnt/ $\beta$-catenin pathway, GSK-3 also coordinates proliferation and differentiation signals through regulation of critical nodes in PI3K, Hh and Notch signaling pathways. Although we found no change in phosphorylation of PKB/Akt (as a marker for PI3K activation, data not shown), examination of overall levels of Hh effector Gli1 via immunoblotting demonstrated Gli1 to be elevated specifically in WAP-TKO tumors (Figure 7b). To assess the contribution of Notch signaling to WAP-TKO TIC activity, Lin $^{-}$TICs 


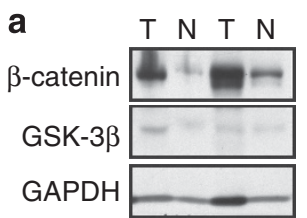

b
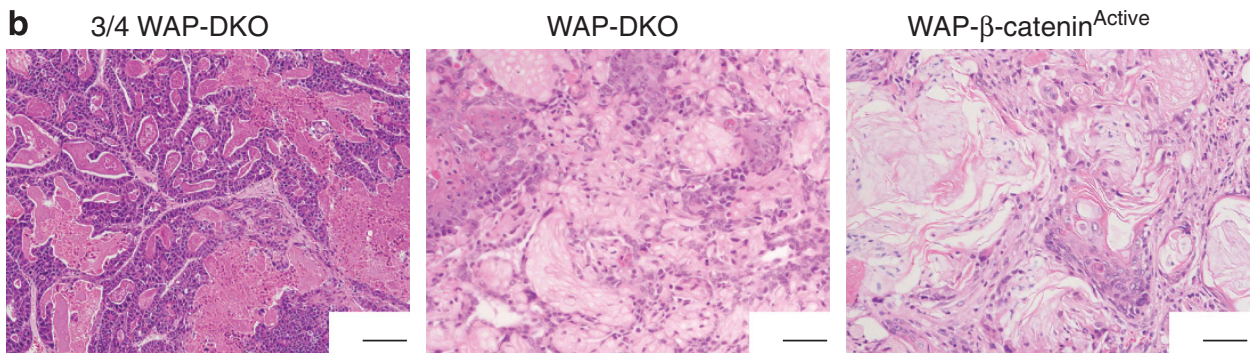

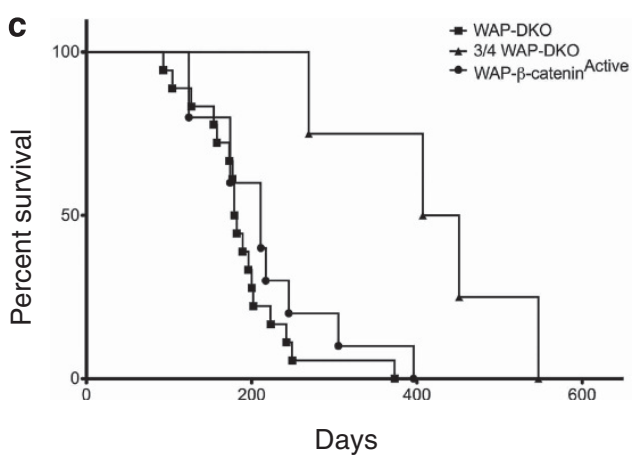

Figure 4. Multiparous WAP-DKOs and WAP- $\beta$-catenin ${ }^{\text {Active }}$ develop adenosquamous carcinomas. (a) Immunoblots of whole-tissue lysates of tumors harvested from two separate multiparous WAP-DKO animals showing loss of GSK-3 $\beta$ and significant elevation of $\beta$-catenin specifically in the tumors (T) when compared with adjacent normal mammary tissue $(\mathrm{N})$. Total number of tumor-bearing animals analyzed, $n=8$ (b) Hematoxylin and eosin staining of tumors arising in transgenics of indicated genotypes showing corresponding histopathology. Total number of tumors analyzed: WAP-DKO, $n=18$; WAP- $\beta$-catenin ${ }^{\text {Active }}, n=10$. (c) Kaplan-Meier survival analysis of tumor-bearing transgenic animals used in the study showing separation of WAP-DKO $(n=18)$ and WAP- $\beta$-catenin ${ }^{\text {Active }}(n=10)$ cohorts from $3 / 4$ WAP-DKOs $(n=4)$. Age of death represents the moment at which, because of the presence of signs of discomfort or because the tumor size exceeded $2 \mathrm{~cm}^{3}$, mice had to be killed according to institutional and national regulations.

were allowed to form spheres and subsequently treated with escalating doses of $\gamma$-secretase inhibitor (Figure 7d). Even at low doses of $\gamma$-secretase inhibitor, a reduction in the number of tumorsphere was observed, whereas secondary tumorsphere formation was completely abrogated (Figure 7d). Taken together, these findings provide evidence that in the absence of GSK-3, strong selective pressure exists for increases in $\gamma$-catenin along with induction of major developmental signaling pathways, $\mathrm{Hh}$ and Notch, which may underlie $\beta$-catenin-independent tumorigenic effects of GSK-3 disruption.

\section{DISCUSSION}

GSK-3 is a primary negative regulator of $\beta$-catenin and we anticipated similar phenotypes of GSK-3 inactivation compared to genetic activation of $\beta$-catenin. Given extensive literature demonstrating that activation of Wnt signaling in mammary epithelium induces squamous differentiation, ${ }^{31,36,37,61,66}$ it was not surprising that the loss of GSK-3 also conferred squamous potential on mammary cells. This phenotype is cell-autonomous and although strikingly similar to that observed upon direct stabilization of $\beta$-catenin, at the stem cell level GSK-3 also exhibits distinct functions. Elevation of $\beta$-catenin results in the generation of a $\mathrm{CD} 24^{\text {hi }}$ population not found in the absence of GSK-3 and this may contribute to the malignant character of $\beta$-catenin tumors. We speculate that MEC response is largely determined by the specific level of $\beta$-catenin and although a lower threshold may be required for epidermoid transdifferentiation common to both WAP-DKOs and WAP- $\beta$-catenin ${ }^{\text {Active }}$ glands, a stronger $\beta$-catenin signal is required for changes associated with malignancy.

GSK-3 inhibits mammary tumorigenesis by restraining signaling via multiple pathways

Deletion of GSK-3 and the ensuing elevation in $\beta$-catenin levels resulted in adenosquamous carcinomas in WAP-DKOs. Although not previously reported, stabilization of endogenous $\beta$-catenin in the mammary epithelium also led to tumors in the present study. These WAP- $\beta$-catenin ${ }^{\text {Active }}$ tumors were histologically similar to those of WAP-DKOs and developed with similar kinetics suggesting that stabilization of $\beta$-catenin is the key requisite step for WAP-DKO tumor formation. Thus, elevation of $\beta$-catenin may permit MECs to re-enter the cell cycle resulting in MIN lesions that progress to adenosquamous carcinomas.

Analysis of $\beta$-catenin-independent tumors formed in the absence of GSK-3 revealed markedly elevated expression of $\mathrm{\gamma}$-catenin/plakoglobin, suggesting a potential compensation mechanism for loss of $\beta$-catenin signaling and/or for its role in cell adhesion. This is consistent with recent findings in embryonic stem cells where $\gamma$-catenin was found to be responsive to GSK-3 inhibition and can activate TCF target genes when the levels of its expression reach a critical threshold. ${ }^{67}$ However, despite their interactions with common cellular partners, $\beta$-catenin has well-documented oncogenic potential whereas $\gamma$-catenin was characterized as having tumor suppressor activity that may be independent of its role in mediating cell-cell adhesion. ${ }^{68-70}$ 

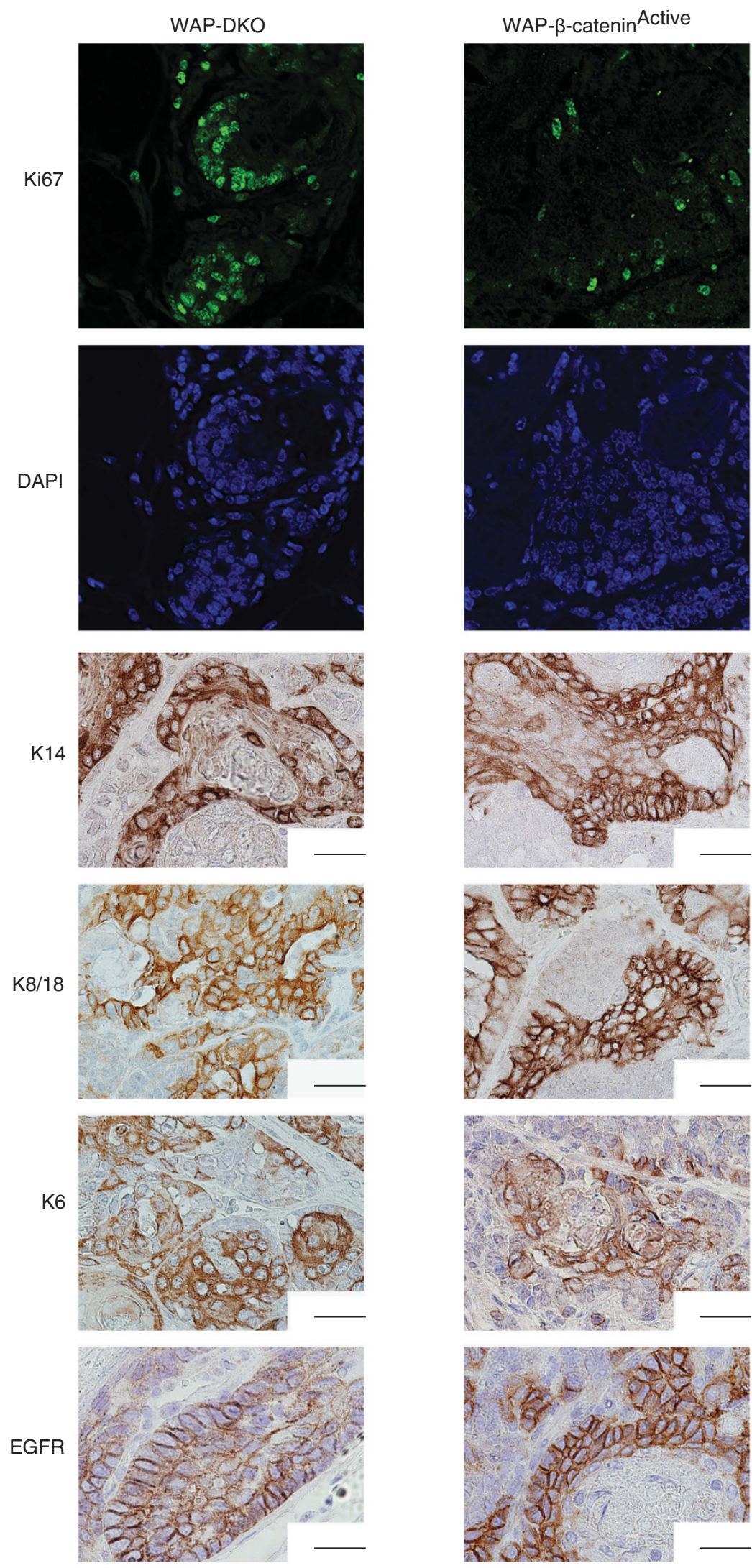

Figure 5. WAP-DKO and WAP- $\beta$-catenin Active tumors display Wnt pathway activation, express luminal and basal markers and EGFR. Representative immunostained sections of tumors harvested from animals of indicated genotypes showing nuclear and cytoplasmic $\beta$-catenin indicative of Wnt pathway activity. On the basis of marker expression, tumors from both WAP-DKOs and WAP- $\beta$-catenin Active transgenics are EGFR-positive and contain luminal and myoepithelial/basal cells. Number of tumors analyzed: WAP-DKO, $n=6$ and WAP- $\beta$-catenin ${ }^{\text {Active }}$ ( $n=3$ ). 
a
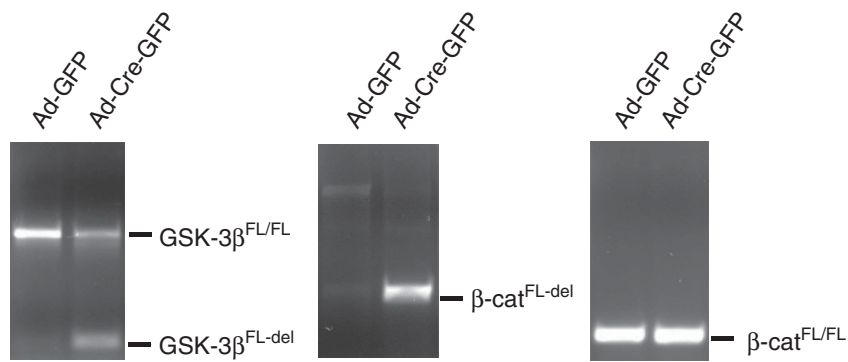

b

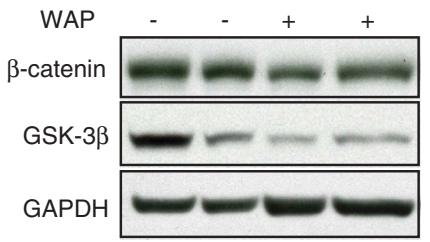

C

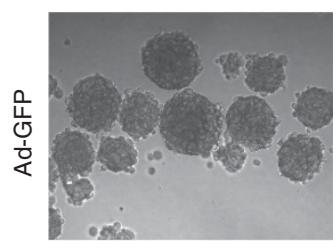

GSK-3 $\alpha^{-/-} ;$GSK-3 $\beta^{\text {FL/FL; } \beta \text {-catenin }}{ }^{\text {Exon 2-6 LoxP/Exon 2-6 LoxP }}$
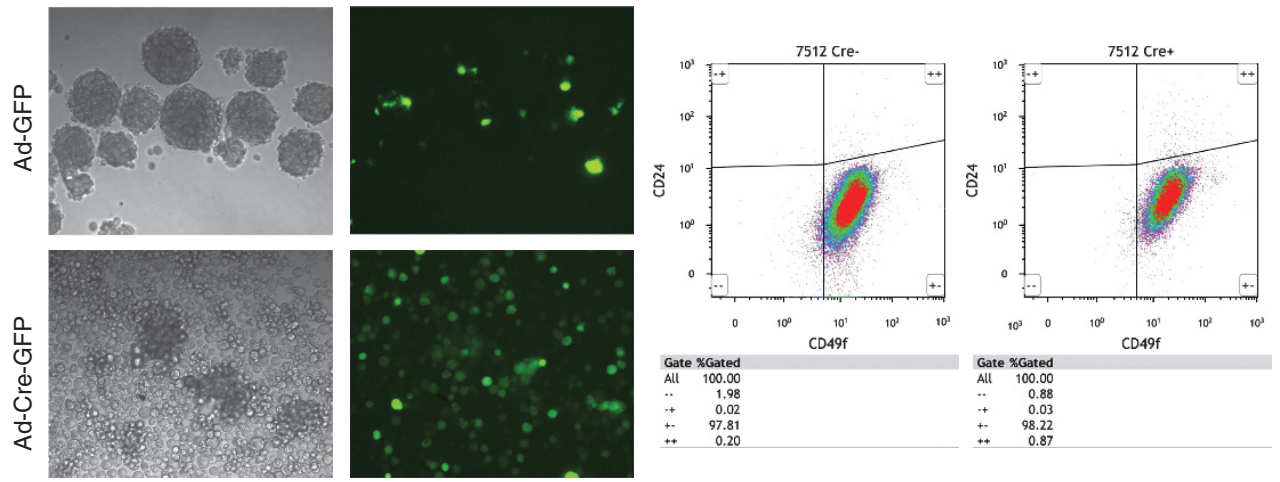

Figure 6. Mammary-selective deletion of GSK-3 and $\beta$-catenin (WAP-TKO) rescues epidermoid transdifferentiation and inhibits MS formation. (a) PCR-based assessment of floxed and excised alleles of GSK-3 3 (850 bp, $250 \mathrm{bp}$ ) and $\beta$-catenin FL-Ex2-6/FL-Ex2-6 (324 bp, $631 \mathrm{bp})$ in mid-pregnant mammary glands from GSK-3 $\alpha^{-/-}$; GSK-3 $\beta^{\mathrm{FL} / F \mathrm{~L}} ; \beta$ - catenin ${ }^{\mathrm{FL}-\mathrm{E} \times 2-6 / \mathrm{FL}-\mathrm{E} \times 2-6}$ mice mediated by WAP-Cre. (b) Representative immunoblot of whole gland lysates from dpc 15 WAP-TKO mice probed with indicated antibodies showing reduced GSK-3 $\beta$ and $\beta$-catenin protein levels. (c) Whereas MS formation proceeded normally in Ad-GFP-infected GSK-3 $\alpha^{-/-} ;$GSK-3 $\beta^{\mathrm{FL} / \mathrm{FL}} ; \beta$-catenin ${ }^{\mathrm{FL}-\mathrm{E} \times 2-6 / \mathrm{FL}-\mathrm{E} \times 2-6}$ MECs, no spheres formed when $\beta$-catenin and GSK-3 were deleted simultaneously. The CD24:CD49f stem cell profile was not affected in TKO MECs. Shown are representative of three separate experiments.

Human tumor analysis has shown loss or reduced expression of $\gamma$-catenin is associated with poor clinical outcome and increased tumor formation and metastasis. ${ }^{71-74}$ The capacity of $\gamma$-catenin to suppress motility and migration may also underlie the lack of metastasis observed in WAP-TKOs and possibly the observed lack of MS formation in TKO MECs.

Despite what may be discerned from the volume of literature linking GSK-3 and Wnt, this protein kinase acts as a nexus in the control of several critical cellular homeostatic mechanisms, in addition to those supplied by $\mathrm{Wnt} / \beta$-catenin. Our results suggest that GSK-3 plays an important role in mediation of $\mathrm{Hh}$ signaling as loss of GSK-3 resulted in elevated Gli1 expression and associated signaling. In addition, enhanced Notch signaling in the absence of GSK-3 may contribute to tumor formation through dysregulation of TIC control. We anticipate that effects of GSK-3 on Wnt, Notch and $\mathrm{Hh}$ signaling are ongoing, however, different proportions of the total GSK-3 pool may participate in the regulation of these pathways. GSK-3 is known to localize to different cellular compartments and may be sequestered in multi-vesicular bodies as recently proposed. ${ }^{75}$ Hence, distribution of GSK-3 may be dependent on cellular context and the events integrated by GSK-3 and the relative strength of their output will determine observed cellular responses. Whereas WAP-TKO tumors showed significant activation of $\mathrm{Hh}$ and $\mathrm{\gamma}$-catenin/plakoglobin, these pathways were essentially unchanged in WAP-DKO tumors suggesting GSK-3 predominantly functions within the $\beta$-catenin destruction complex to regulate the Wnt pathway when $\beta$-catenin is intact.

\section{MATERIALS AND METHODS}

Generation of mouse strains used in the study

All animals were housed at the Toronto Centre for Phenogenomics (www. phenogenomics.ca). GSK-3 $a^{-/-}$and GSK-3 $\beta^{\text {Exon2 LoxP/Exon2 LoxP }}$ (referred to as GSK-3 $\beta^{\mathrm{FL} / \mathrm{FL}}$ ) mutants and their wild-type littermates were generated as previously described. ${ }^{76,77} \mathrm{GSK}-3 a^{-1-}$ and GSK-3$\beta^{\mathrm{FL} / \mathrm{FL}}$ mice were six generations backcrossed to FVB mice. At weaning, all littermates of mixed genotypes were housed by gender in groups of three to five per cage under a 12-h light/dark cycle (lights on at 0700) with ad libitum food (Purina mouse chow, Purina, St Louis, MO, USA) and water. To generate mammary gland-specific GSK-3 knockout (KO) mice, GSK-3 $\beta^{\mathrm{FL} / \mathrm{FL}}$ animals were crossed with B6.Cg-Tg(Wap-Cre)11738Mam (obtained from Sean Egan, Hospital for Sick Children), which carries Cre recombinase under the control of the WAP promoter. WAP-Cre; GSK- $3 \beta^{\mathrm{FL} / \mathrm{FL}}$ animals were then mated with GSK-3a $a^{-1-}$ to generate WAP-Cre; GSK- $3 a^{-1-} ; \mathrm{GSK}-3 \beta^{\mathrm{FL} / \mathrm{FL}}$, designated WAP-DKO, denoting them as mammary specific GSK-3 DKO. WAP-Cre and WAP-DKOs were also crossed to B6.129-Ctnnb1 $1^{\mathrm{tm} 2 \mathrm{Kem}} / \mathrm{KnwJ}$ (backcrossed onto FVB for six generations) bearing the exon 2-6 floxed allele of $\beta$-catenin ( $\beta$-catenin ${ }^{\text {Exon } 2-6 \text { LoxP/+ }}$, referred to as $\beta$-catenin $\left.{ }^{\mathrm{FL}-\mathrm{Ex} 2-6 /+}\right)$. This enabled generation of WAP-Cre; $\beta$-catenin $n^{\mathrm{FL}-\mathrm{E} \times 2-6 / \mathrm{FL}-\mathrm{E} \times 2-6}$ and WAP-Cre; GSK-3a ${ }^{-1-} ; \quad$ GSK-3 $\beta^{\mathrm{FL} / F \mathrm{LL}} ; \beta$-catenin ${ }^{\mathrm{FL}-\mathrm{E} \times 2-6 / F \mathrm{~L}-\mathrm{E} \times 2-6}$, or TKO referred as 
a

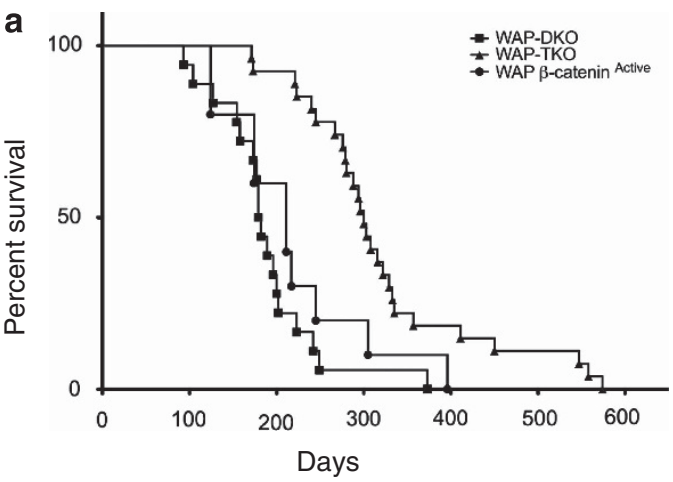

c
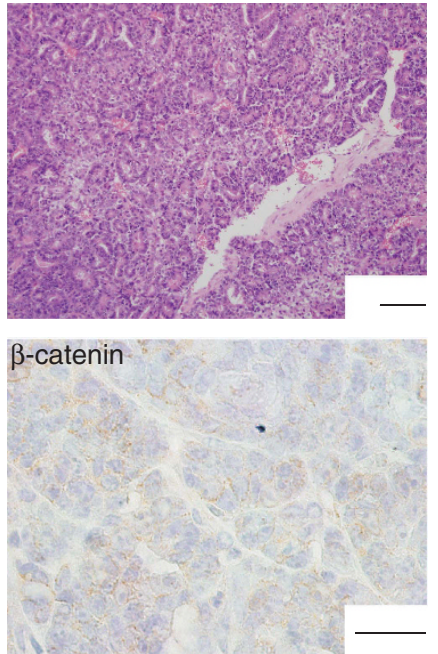

e
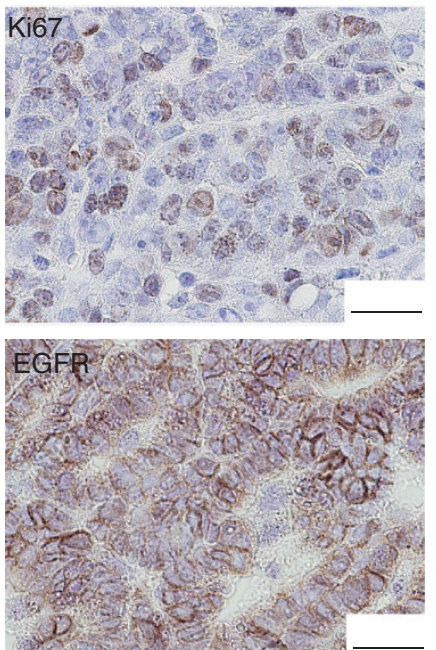
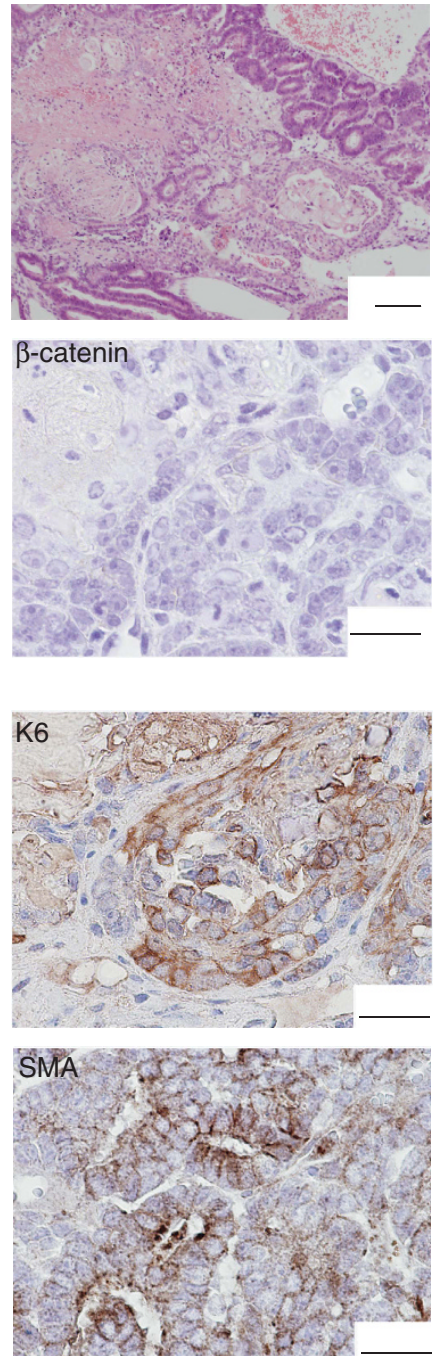

b

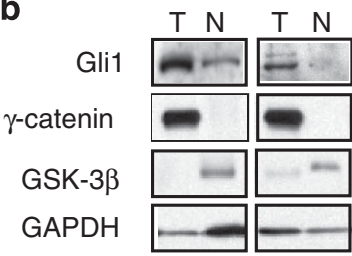

d
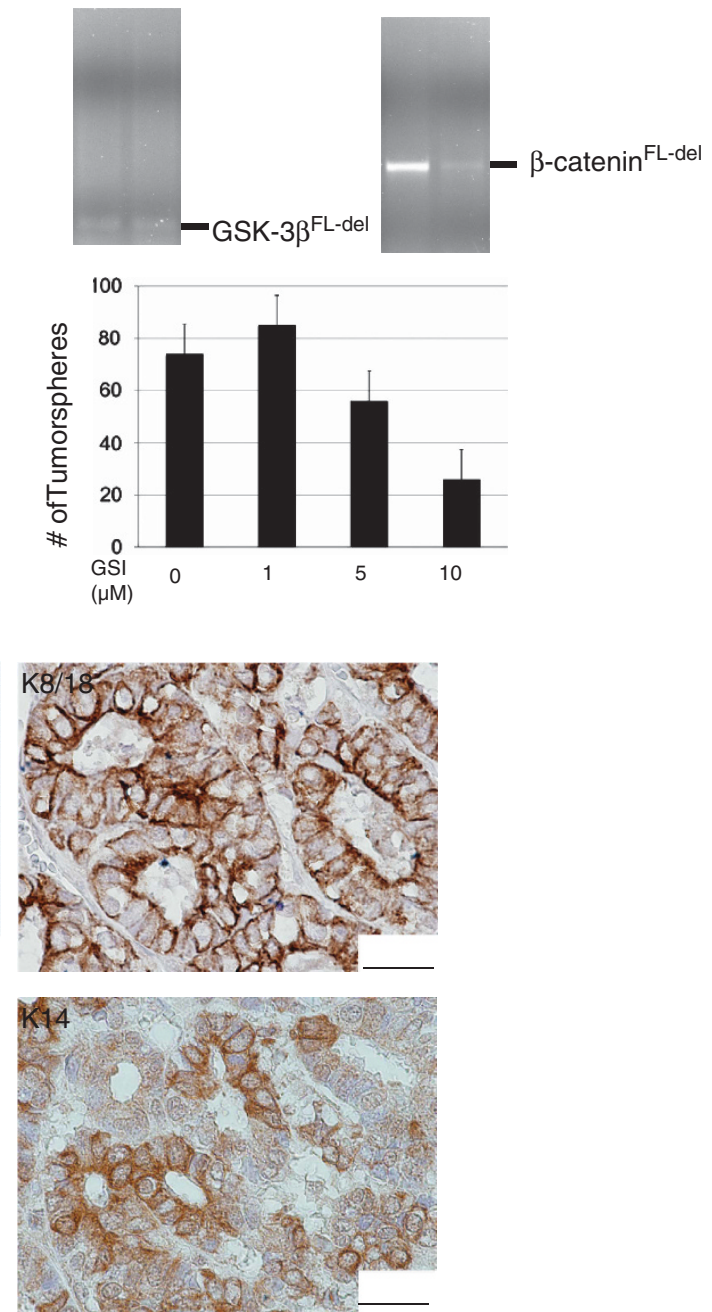

Figure 7. Mixed histopathology of tumors arise following long latency in WAP-TKO mice. (a) Kaplan-Meier survival analysis of tumor-bearing transgenics showing separation of WAP-TKOs $(n=27)$ from both WAP-DKO $(n=18)$ and WAP- $\beta$-catenin Active $(n=10)$ cohorts. (b) Immunoblot showing loss of GSK-3 $\beta$ and elevated levels of Gli1 and $\gamma$-catenin specifically in WAP-TKO tumors. GAPDH serves as loading control (T, tumor; $\mathrm{N}$, normal). Total number of tumors analyzed, $n=10$. (c) WAP-TKO tumors are largely adenocarcinomas that contain elements of squamous differentiation (top panels) with no $\beta$-catenin staining in either histological component. Total number of tumors analyzed $n=27$. (d) WAP-TKO tumor cells were purified, allowed to form tumorsphere and subsequently treated in triplicates with increasing concentrations of $\gamma$-secretase inhibitor as indicated. Tumorsphere were counted on day 7 of treatment (bottom panel). Efficient excision at the GSK-3 $\beta$ and $\beta$-catenin was confirmed by PCR genotyping of tumorsphere (top panel) from two separate tumors. (e) Representative immunostained sections of WAP-TKO tumors showing expression of luminal and myoepithelial/basal markers, proliferation as well as presence of K6, EGFR and SMA. Total number of tumors analyzed, $n=8$. 
WAP-TKO WAP-Cre mice were also mated to $\beta$-catenin ${ }^{\text {Exon } 3 \text { LoxP/+ }}$ (referred to as $\beta$-catenin ${ }^{\mathrm{FL}-\mathrm{Ex} 3 /+}$ ) transgenics (obtained with permission from Makoto M. Taketo and Derek van der Kooy, University of Toronto) previously described $^{78}$ to generate WAP- $\beta$-catenin ${ }^{\text {Active }}$ mice.

\section{BrdU injection}

Intraperitoneal injections of mice were performed using BrdU (BD Pharmingen, Mississauga, ON, Canada) at $100 \mu \mathrm{g} / \mathrm{g}$ body weight. Incorporation of BrdU was detected $4 \mathrm{~h}$ post injection using $\mathrm{IHC}$ as described in 'Histology and immunostaining of tissue sections'.

Mammary epithelial single-cell preparation, enrichment and flow cytometry analysis

Mammary tumors or glands from mice killed at indicated developmental time points were dissected and digested in $1 \mathrm{X}$ Collagenase/Hyaluronidase (StemCell Technologies 07912, Vancouver, BC, Canada) diluted in DMEMF12 and incubated at $4{ }^{\circ} \mathrm{C}$ overnight and then at $37^{\circ} \mathrm{C}$ for $30 \mathrm{~min}$, passed through a $40 \mu \mathrm{m}$ cell strainer (BD Falcon, Mississauga, ON, Canada) and pelleted by centrifugation at 1000 r.p.m. for $5 \mathrm{~min}$ at room temperature (RT). Enrichment of Lin ${ }^{-}$MEC was achieved through selective depletion of hematopoietic, endothelial and stromal cells using an EasySep kit (StemCell Technologies 19757) according to manufacturer's directions. $\mathrm{Lin}^{-}$cells were then stained with anti-CD49f clone GoH3 conjugated with either R-phycoerythrin, FITC or APC (CD49f-PE, CD49f-FITC, CD49f-APC), anti-CD24 clone M1/69 conjugated with PE, FITC or PerCP-eFluor 710 (CD24-PE, CD24-FITC, CD24-PerCP-eFluor 710) as well as 7aminoactinomycin D, SYTOX Blue (Life Technologies, Mississauga, ON Canada) or DAPI for 30 min at RT. HBSS containing $2 \%$ FBS (referred to as HF) was used as buffer. Live single cells (fixed FSC-A/FSC-W ratio; 7-aminoactinomycin D, SYTOX or DAPI-negative) were gated for analysis. Flow cytometry acquisition was performed using FACSCalibur (Becton Dickinson, Mississauga, ON, Canada) or Gallios (Beckman Coulter, Mississauga, ON, Canada) flow cytometer using a 10-color, 4-laser $(488 \mathrm{~nm}$ blue, $561 \mathrm{~nm}$ yellow [co-linear], $638 \mathrm{~nm}$ red, $404 \mathrm{~nm}$ violet) at standard filter configuration. Fluorescence-activated cell sorting was carried out using FACSAria-13 color Cell Sorter (Becton Dickinson) with $488 \mathrm{~nm}$ blue laser at 30 p.s.i. All antibodies were titrated to determine the optimal antibody concentration. Briefly, TICs, MECs or MECs expressing GFP were stained with CD24 and CD49f (conjugated to appropriate fluorophore) and SYTOX Blue or 7-aminoactinomycin D and fluorescenceminus-one controls were used to determine the CD24 and CD49f gates. Flow cytometry analysis was performed using the Kaluza analysis software package (Beckman Coulter).

\section{MS and tumorsphere culturing in vitro}

Immediately following EasySep Magnet incubation (see above), a singlecell suspension of Lin ${ }^{-}$MECs was infected with adenovirus-GFP (Ad-GFP) or adenovirus-Cre-GFP (Ad-Cre-GFP) at a multiplicity of infection of 50 . Virus was allowed to adsorb to cells for $1 \mathrm{~h}$ at $37^{\circ} \mathrm{C}$ with gentle agitation every 10 min. Infected MECs (for MS) or enriched TICs (for TC) were then plated on ultra-low attachment plates (Corning, Costar, Tewksbury, MA, USA) in DMEM/F-12 HAM medium (Sigma, Markham, ON, Canada) containing $20 \mathrm{ng} / \mathrm{ml}$ basic fibroblast growth factor (StemCell Technologies), $20 \mathrm{ng} / \mathrm{ml}$ epidermal growth factor (StemCell Technologies) and B-27 supplement (1:50 dilution, Life Technologies) and cultured in a standard tissue culture incubator. Spheres were dissociated at 7-day intervals as follows: spheres were collected in a single tube, spun down and supernatant removed. MS were resuspended in $100 \mu \mathrm{l}$ of $0.25 \%$ trypsin and incubated for $1 \mathrm{~min}$ at RT followed by $1 \mathrm{~min}$ of mechanical disruption by passage through a $1 \mathrm{ml}$ syringe with a 26-gauge needle. HF $(900 \mu l)$ was added to neutralize the trypsin and cells were counted and re-plated. To enumerate spheres, prior to enzymatic and mechanical dissociation, spheres were resuspended in a known volume and a 10th of suspension was transferred to a well of a 96well plate and all spheres were counted. Images were captured using Hamamatsu camera (Bridgewater, NJ, USA) mounted on a Leica inverted DMIRB microscope (Concord, ON, Canada) equipped with Volocity software (Perkin-Elmer, Waltham, MA, USA).

\section{Transplantation}

Sorted tumor cells or Lin $^{-}$MECs $48 \mathrm{~h}$ post-Ad-infection were resuspended in DMEM-F12 medium and mixed at a 1:1 ratio with Matrigel (BD Bioscience, Mississauga, ON, Canada) on ice. One milliliter of Trypan Blue solution (Life Technologies) was added to all samples to enable visualization during injection. A mixture of Matrigel and 1,2 or $10 \times 10^{3}$ tumor cells was injected using a Hamilton syringe near the upper \#4 mammary fat pads of 6-8-week-old virgin FVB mice anesthetized with isoflurane. Similarly, $50 \times 10^{3}$ of adenovirus-infected MECs were mixed 1:1 with Matrigel and injected into cleared \#4 mammary fat pad and analyzed 8 weeks later.

\section{Histology and immunostaining of tissue sections}

Mammary glands (thoracic) were harvested at indicated developmental time points. Tumors were harvested at tumor endpoint. Tissues were fixed in $4 \%$ paraformaldehyde overnight at $4{ }^{\circ} \mathrm{C}$ and placed in $70 \%$ ethanol until they were paraffin-embedded. Five micrometer paraffin sections were stained with hematoxylin and eosin. Tissue sections were deparaffinized in two 5-min changes of xylenes, rehydrated in graduated ethanols and then washed in phosphate-buffered saline (PBS). With the exception of EGFR staining where $1 \mathrm{~mm}$ EDTA ( $\mathrm{pH}$ 8) was used, antigen retrieval was performed using $10 \mathrm{~mm}$ citrate buffer $(\mathrm{pH} \mathrm{6)}$ in a microwave at $10 \mathrm{~min}$ boiling following $10 \mathrm{~min}$ sub-boiling. Slides were cooled for $30 \mathrm{~min}$. For $\mathrm{IHC}$, endogenous peroxidase activity was quenched by incubating sections in $0.3 \%$ hydrogen peroxide for $30 \mathrm{~min}$ followed by blocking in $5 \%$ goat serum in PBS for $30 \mathrm{~min}$ or $5 \%$ goat serum in Tris-buffered saline (TBS) containing $0.1 \%$ Tween-20 (TBST) for EGFR staining. For immunofluorescence (IF), sections were blocked for $30 \mathrm{~min}$ in IF buffer (PBS+0.2\% Triton $X-100,0.05 \%$ Tween-20) containing $2 \%$ bovine serum albumin (BSA). Sections were then incubated in primary antibody (Supplementary Table 1) overnight at $4{ }^{\circ} \mathrm{C}$ in $2 \%$ BSA-PBS. Following washes with PBS for IHC or IF buffer for IF, sections were incubated for $1 \mathrm{~h}$ at RT with biotinylated (Dako, Burlington, ON, Canada) or Alexa Fluor (Life Technologies)-conjugated secondary antibodies for $\mathrm{IHC}$ or IF, respectively. For $\mathrm{IHC}$, the peroxidase reaction was carried out using DAB substrate (Dako) and sections were counterstained with hematoxylin and mounted in Faramount (Dako) aqueous mounting medium. For IF, sections were mounted in ProLong Gold Antifade Reagent with DAPI (Life Technologies). IHC images were digitally captured with an Olympus digital DP 12 megapixel color camera (Olympus, Richmond Hill, ON, Canada) mounted on the Olympus BX61 motorized microscope (Olympus). IF images were captured using a Deltavision deconvolution microscope (Applied Precision Inc. Issaquah, WA, USA), that consisted of an Olympus Inverted IX70 microscope (Olympus) and motorized stage. Images were projected onto a Coolsnap CCD camera (Photometrics, Tucson, AZ, USA) and processed through Softworx software (GE Healthcare, Mississauga, ON, Canada) that contained iterative deconvolution algorithms.

\section{Immunoblotting}

Fifty milligram of tissue or tumor was lysed in $1 \mathrm{ml}$ of RIPA lysis buffer supplemented with complete protease inhibitor tablet (Roche, Laval, QC, Canada) and phosphatase inhibitor cocktail (Sigma) using TissueLyser (Qiagen, Mississauga, ON, Canada). Lysates were cleared by centrifugation for $15 \mathrm{~min}$ at $4{ }^{\circ} \mathrm{C}$ and protein concentration determined by Lowry assay (Bio-Rad, Mississauga, ON, Canada). Protein lysates (10-30 $\mu \mathrm{g})$ containing SDS sample buffer were boiled for $5 \mathrm{~min}$ and loaded onto an 8 or $10 \%$ SDS-PAGE gel, followed by semi-dry transfer onto polyvinylidene difluoride membrane (Millipore, Etobicoke, ON, Canada). Blocking was performed for $1 \mathrm{~h}$ at RT in 5\% non-fat milk in TBST and membranes were probed with primary antibodies (Supplementary Table 1) overnight at $4{ }^{\circ} \mathrm{C}$. Following washes with TBST, membranes were incubated with appropriate HRP-conjugated secondary antibodies (Bio-Rad) for $45 \mathrm{~min}$ at RT, washed and exposed to film (Kodak, Burnaby, BC, Canada) using ECL reagent (Pierce, Thermo-Fisher Scientific, Burlington, ON, Canada).

\section{Genotyping}

Mouse tail tips were digested in $200 \mathrm{~mm}$ Tris $\mathrm{HCl}$ pH 8.4, $500 \mathrm{~mm} \mathrm{KCl}$ containing NP40, Tween-20 and Proteinase $\mathrm{K}$ at $60^{\circ} \mathrm{C}$ for $2 \mathrm{~h}$. Genotyping of the mice was performed using one pair of appropriate primers (Supplementary Table 2).

\section{CONFLICT OF INTEREST}

The authors declare no conflict of interest. 


\section{ACKNOWLEDGEMENTS}

We thank Tao Deng, Hartland W Jackson and Purna A Joshi for assistance with mammary gland manipulation and Katrina MacAulay, Brad Doble and Satish Patel for their generation of mice harboring floxed GSK-3 alleles. We wish to thank Tara Paton of The Centre for Applied Genomics (TCAG), The Hospital for Sick Children, Toronto, for assistance with Sanger sequencing and Yanchun Wang of the Centre for Modeling Human Disease Pathology (CMHD) and Cryopreservation Core at the Toronto Centre for Phenogenomics for laser-capture microdissection. This work was supported by grants to JRW from the CBCRA, CIHR (MOP74711) and Terry Fox Foundation team grant to EZ. JD was partially supported by a CBCF (Ontario) doctoral fellowship.

\section{AUTHOR CONTRIBUTIONS}

$J D$ and $J C L$ designed, performed and analyzed the experiments; HAA performed pathological examination and classification of tumor samples, JRW and EZ supervised research; JD and JRW conceived the project and prepared the manuscript; all authors commented on the manuscript.

\section{REFERENCES}

1 Makarem M, Spike BT, Dravis C, Kannan N, Wahl GM, Eaves CJ. Stem cells and the developing mammary gland. J Mamm Gland Biol Neoplasia 2013; 18: 209-219.

2 Visvader JE. Keeping abreast of the mammary epithelial hierarchy and breast tumorigenesis. Genes Dev 2009; 23: 2563-2577.

3 Makarem M, Kannan N, Nguyen LV, Knapp DJ, Balani S, Prater MD et al. Developmental changes in the in vitro activated regenerative activity of primitive mammary epithelial cells. PLoS Biol 2013; 11: e1001630.

4 Clevers H, Nusse R. Wnt/beta-catenin signaling and disease. Cell 2012; 149 : 1192-1205.

5 Li VS, Ng SS, Boersema PJ, Low TY, Karthaus WR, Gerlach JP et al. Wnt signaling through inhibition of beta-catenin degradation in an intact Axin1 complex. Cell 2012; 149: 1245-1256.

6 Kim WY, Wang X, Wu Y, Doble BW, Patel S, Woodgett JR et al. GSK-3 is a master regulator of neural progenitor homeostasis. Nat Neurosci 2009; 12: 1390-1397.

7 Radulescu S, Ridgway RA, Cordero J, Athineos D, Salgueiro P, Poulsom R et al. Acute WNT signalling activation perturbs differentiation within the adult stomach and rapidly leads to tumour formation. Oncogene 2013; 32: 2048-2057.

8 Chen Y, Yue S, Xie L, Pu XH, Jin T, Cheng SY. Dual Phosphorylation of suppressor of fused (Sufu) by PKA and GSK3beta regulates its stability and localization in the primary cilium. J Biol Chem 2011; 286: 13502-13511.

9 Jia J, Amanai K, Wang G, Tang J, Wang B, Jiang J. Shaggy/GSK3 antagonizes Hedgehog signalling by regulating Cubitus interruptus. Nature 2002; 416: 548-552.

10 Kise Y, Morinaka A, Teglund S, Miki H. Sufu recruits GSK3beta for efficient processing of Gli3. Biochem Biophys Res Commun 2009; 387: 569-574.

11 Price MA, Kalderon D. Proteolysis of the Hedgehog signaling effector Cubitus interruptus requires phosphorylation by Glycogen Synthase Kinase 3 and Casein Kinase 1. Cell 2002; 108: 823-835.

12 Espinosa L, Ingles-Esteve J, Aguilera C, Bigas A. Phosphorylation by glycogen synthase kinase-3 beta down-regulates Notch activity, a link for Notch and Wnt pathways. J Biol Chem 2003; 278: 32227-32235.

13 Foltz DR, Santiago MC, Berechid BE, Nye JS. Glycogen synthase kinase-3beta modulates notch signaling and stability. Curr Biol 2002; 12: 1006-1011.

14 Jin $\mathrm{YH}, \mathrm{Kim} \mathrm{H}, \mathrm{Oh} \mathrm{M}, \mathrm{Ki} \mathrm{H}, \mathrm{Kim}$ K. Regulation of Notch1/NICD and Hes1 expressions by GSK-3alpha/beta. Mol Cells 2009; 27: 15-19.

15 Hayes MJ, Thomas D, Emmons A, Giordano TJ, Kleer CG. Genetic changes of Wnt pathway genes are common events in metaplastic carcinomas of the breast. Clin Cancer Res 2008; 14: 4038-4044.

16 Hennessy BT, Gonzalez-Angulo AM, Stemke-Hale K, Gilcrease MZ, Krishnamurthy $S$, Lee JS et al. Characterization of a naturally occurring breast cancer subset enriched in epithelial-to-mesenchymal transition and stem cell characteristics. Cancer Res 2009; 69: 4116-4124.

17 Khramtsov Al, Khramtsova GF, Tretiakova M, Huo D, Olopade Ol, Goss KH. Wnt/beta-catenin pathway activation is enriched in basal-like breast cancers and predicts poor outcome. Am J Pathol 2010; 176: 2911-2920.

18 Lacroix-Triki M, Geyer FC, Lambros MB, Savage K, Ellis IO, Lee AH et al. beta-catenin/Wnt signalling pathway in fibromatosis, metaplastic carcinomas and phyllodes tumours of the breast. Modern Pathol 2010; 23: 1438-1448.

19 Dolled-Filhart M, McCabe A, Giltnane J, Cregger M, Camp RL, Rimm DL. Quantitative in situ analysis of beta-catenin expression in breast cancer shows decreased expression is associated with poor outcome. Cancer Res 2006; 66: 5487-5494.

20 Ozaki S, Ikeda S, Ishizaki Y, Kurihara T, Tokumoto N, Iseki M et al. Alterations and correlations of the components in the Wnt signaling pathway and its target genes in breast cancer. Oncol Rep 2005; 14: 1437-1443.
21 Ai L, Tao Q, Zhong S, Fields CR, Kim WJ, Lee MW et al. Inactivation of Wnt inhibitory factor-1 (WIF1) expression by epigenetic silencing is a common event in breast cancer. Carcinogenesis 2006; 27: 1341-1348.

22 Gauger KJ, Hugh JM, Troester MA, Schneider SS. Down-regulation of sfrp1 in a mammary epithelial cell line promotes the development of a cd44high/cd24low population which is invasive and resistant to anoikis. Cancer Cell Int 2009; 9: 11.

23 Wong SC, Lo SF, Lee KC, Yam JW, Chan JK, Wendy Hsiao WL. Expression of frizzled-related protein and Wnt-signalling molecules in invasive human breast tumours. J Pathol 2002; 196: 145-153.

24 Reya T, Clevers H. Wht signalling in stem cells and cancer. Nature 2005; 434: 843-850.

25 Zeng YA, Nusse R. Wht proteins are self-renewal factors for mammary stem cells and promote their long-term expansion in culture. Cell Stem Cell 2010; 6: 568-577.

26 Liu BY, McDermott SP, Khwaja SS, Alexander CM. The transforming activity of Wnt effectors correlates with their ability to induce the accumulation of mammary progenitor cells. Proc Natl Acad Sci USA 2004; 101: 4158-4163.

27 Li Y, Welm B, Podsypanina K, Huang S, Chamorro M, Zhang X et al. Evidence that transgenes encoding components of the Wnt signaling pathway preferentially induce mammary cancers from progenitor cells. Proc Natl Acad Sci USA 2003; 100: 15853-15858.

28 van Amerongen R, Bowman AN, Nusse R. Developmental stage and time dictate the fate of Wnt/beta-catenin-responsive stem cells in the mammary gland. Cell Stem Cell 2012; 11: 387-400.

29 Gallagher RC, Hay T, Meniel V, Naughton C, Anderson TJ, Shibata H et al. Inactivation of Apc perturbs mammary development, but only directly results in acanthoma in the context of Tcf-1 deficiency. Oncogene 2002; 21: 6446-6457.

30 Miyoshi K, Hennighausen L. Beta-catenin: a transforming actor on many stages. Breast Cancer Res 2003; 5: 63-68.

31 Miyoshi K, Shillingford JM, Le Provost F, Gounari F, Bronson R, von Boehmer H et al. Activation of beta -catenin signaling in differentiated mammary secretory cells induces transdifferentiation into epidermis and squamous metaplasias. Proc Natl Acad Sci USA 2002; 99: 219-224.

32 Renou JP, Bierie B, Miyoshi K, Cui Y, Djiane J, Reichenstein M et al. Identification of genes differentially expressed in mouse mammary epithelium transformed by an activated beta-catenin. Oncogene 2003; 22: 4594-4610.

33 Imbert A, Eelkema R, Jordan S, Feiner H, Cowin P. Delta N89 beta-catenin induces precocious development, differentiation, and neoplasia in mammary gland. J Cell Biol 2001; 153: 555-568.

34 Michaelson JS, Leder P. beta-catenin is a downstream effector of Wnt-mediated tumorigenesis in the mammary gland. Oncogene 2001; 20: 5093-5099.

35 Teuliere J, Faraldo MM, Deugnier MA, Shtutman M, Ben-Ze'ev A, Thiery JP et al. Targeted activation of beta-catenin signaling in basal mammary epithelial cells affects mammary development and leads to hyperplasia. Development 2005; 132: 267-277.

36 Landesman-Bollag E, Romieu-Mourez R, Song DH, Sonenshein GE, Cardiff RD, Seldin DC. Protein kinase CK2 in mammary gland tumorigenesis. Oncogene 2001; 20: 3247-3257.

37 Wang TC, Cardiff RD, Zukerberg L, Lees E, Arnold A, Schmidt EV. Mammary hyperplasia and carcinoma in MMTV-cyclin D1 transgenic mice. Nature 1994; 369: 669-671.

38 Callahan R, Egan SE. Notch signaling in mammary development and oncogenesis. J Mamm Gland Biol Neoplasia 2004; 9: 145-163.

39 Parr C, Watkins G, Jiang WG. The possible correlation of Notch-1 and Notch- 2 with clinical outcome and tumour clinicopathological parameters in human breast cancer. Int J Mol Med 2004; 14: 779-786.

40 Robinson DR, Kalyana-Sundaram S, Wu YM, Shankar S, Cao X, Ateeq B et al. Functionally recurrent rearrangements of the MAST kinase and Notch gene families in breast cancer. Nat Med 2011; 17: 1646-1651.

41 Bouras T, Pal B, Vaillant F, Harburg G, Asselin-Labat ML, Oakes SR et al. Notch signaling regulates mammary stem cell function and luminal cell-fate commitment. Cell Stem Cell 2008; 3: 429-441.

42 Dontu G, Jackson KW, McNicholas E, Kawamura MJ, Abdallah WM, Wicha MS. Role of Notch signaling in cell-fate determination of human mammary stem/progenitor cells. Breast Cancer Res 2004; 6: R605-R615.

43 Ling H, Sylvestre JR, Jolicoeur P. Notch1-induced mammary tumor development is cyclin D1-dependent and correlates with expansion of pre-malignant multipotent duct-limited progenitors. Oncogene 2010; 29: 4543-4554.

44 Raouf A, Zhao Y, To K, Stingl J, Delaney A, Barbara M et al. Transcriptome analysis of the normal human mammary cell commitment and differentiation process. Cell Stem Cell 2008; 3: 109-118.

45 Yalcin-Ozuysal O, Fiche M, Guitierrez M, Wagner KU, Raffoul W, Brisken C. Antagonistic roles of Notch and p63 in controlling mammary epithelial cell fates. Cell Death Diff 2010; 17: 1600-1612. 
46 Sale S, Lafkas D, Artavanis-Tsakonas S. Notch2 genetic fate mapping reveals two previously unrecognized mammary epithelial lineages. Nat Cell Biol 2013; 15 451-460.

47 Hui M, Cazet A, Nair R, Watkins DN, O'Toole SA, Swarbrick A. The Hedgehog signalling pathway in breast development, carcinogenesis and cancer therapy. Breast Cancer Res 2013; 15: 203.

48 Kubo M, Nakamura M, Tasaki A, Yamanaka N, Nakashima H, Nomura M et al. Hedgehog signaling pathway is a new therapeutic target for patients with breast cancer. Cancer Res 2004; 64: 6071-6074.

49 O'Toole SA, Machalek DA, Shearer RF, Millar EK, Nair R, Schofield P et al. Hedgehog overexpression is associated with stromal interactions and predicts for poor outcome in breast cancer. Cancer Res 2011; 71: 4002-4014.

50 Kameda C, Nakamura M, Tanaka H, Yamasaki A, Kubo M, Tanaka M et al. Oestrogen receptor-alpha contributes to the regulation of the hedgehog signalling pathway in ERalpha-positive gastric cancer. $\mathrm{Br} J$ Cancer 2010; 102 738-747.

51 Xu L, Kwon YJ, Frolova N, Steg AD, Yuan K, Johnson MR et al. Gli1 promotes cell survival and is predictive of a poor outcome in ERalpha-negative breast cancer Breast Cancer Res Treat 2010; 123: 59-71.

52 Moraes RC, Zhang X, Harrington N, Fung JY, Wu MF, Hilsenbeck SG et al. Constitutive activation of smoothened (SMO) in mammary glands of transgenic mice leads to increased proliferation, altered differentiation and ductal dysplasia. Development 2007; 134: 1231-1242.

53 Li N, Singh S, Cherukuri P, Li H, Yuan Z, Ellisen LW et al. Reciprocal intraepithelia interactions between TP63 and hedgehog signaling regulate quiescence and activation of progenitor elaboration by mammary stem cells. Stem Cells 2008; $\mathbf{2 6}$ 1253-1264.

54 Kasper M, Jaks V, Fiaschi M, Toftgard R. Hedgehog signalling in breast cancer. Carcinogenesis 2009; 30: 903-911.

55 Liu S, Dontu G, Mantle ID, Patel S, Ahn NS, Jackson KW et al. Hedgehog signaling and Bmi-1 regulate self-renewal of normal and malignant human mammary stem cells. Cancer Res 2006; 66: 6063-6071.

56 Fiaschi M, Rozell B, Bergstrom A, Toftgard R. Development of mammary tumors by conditional expression of GLI1. Cancer Res 2009; 69: 4810-4817.

57 Fiaschi M, Rozell B, Bergstrom A, Toftgard R, Kleman MI. Targeted expression of GLI1 in the mammary gland disrupts pregnancy-induced maturation and causes lactation failure. J Biol Chem 2007; 282: 36090-36101.

58 Booth BW, Boulanger CA, Smith GH. Alveolar progenitor cells develop in mouse mammary glands independent of pregnancy and lactation. J Cell Physiol 2007 212: 729-736.

59 Robinson GW, McKnight RA, Smith GH, Hennighausen L. Mammary epithelia cells undergo secretory differentiation in cycling virgins but require pregnancy for the establishment of terminal differentiation. Development 1995; 121 2079-2090

60 Wagner KU, Boulanger CA, Henry MD, Sgagias M, Hennighausen L, Smith GH. An adjunct mammary epithelial cell population in parous females: its role in functional adaptation and tissue renewal. Development 2002; 129 1377-1386.

61 Miyoshi K, Rosner A, Nozawa M, Byrd C, Morgan F, Landesman-Bollag E et al. Activation of different Wnt/beta-catenin signaling components in mammary epithelium induces transdifferentiation and the formation of pilar tumors Oncogene 2002; 21: 5548-5556.

62 Bu W, Chen J, Morrison GD, Huang S, Creighton CJ, Huang J et al. Keratin 6a marks mammary bipotential progenitor cells that can give rise to a unique tumor model resembling human normal-like breast cancer. Oncogene 2011; 30 4399-4409.
63 Sun P, Yuan Y, Li A, Li B, Dai X. Cytokeratin expression during mouse embryonic and early postnatal mammary gland development. Histochem Cell Biol 2010; 133: 213-221.

64 Dontu G, Wicha MS. Survival of mammary stem cells in suspension culture: implications for stem cell biology and neoplasia. J Mamm Gland Biol Neoplasia 2005; 10: 75-86.

65 McCrea PD, Turck CW, Gumbiner B. A homolog of the armadillo protein in Drosophila (plakoglobin) associated with E-cadherin. Science 1991; 254: 1359-1361.

66 Kuraguchi M, Ohene-Baah NY, Sonkin D, Bronson RT, Kucherlapati R. Genetic mechanisms in Apc-mediated mammary tumorigenesis. PLoS Genet 2009; 5: e1000367.

67 Mahendram S, Kelly KF, Paez-Parent S, Mahmood S, Polena E, Cooney AJ et al Ectopic gamma-catenin expression partially mimics the effects of stabilized beta-catenin on embryonic stem cell differentiation. PLoS One 2013; 8: e65320.

68 Aktary Z, Pasdar M. Plakoglobin: role in tumorigenesis and metastasis. Int J Cell Biol 2012; 2012: 189521.

69 Lam L, Aktary Z, Bishay M, Werkman C, Kuo CY, Heacock M et al. Regulation of subcellular distribution and oncogenic potential of nucleophosmin by plakoglobin. Oncogenesis 2012; 1: e4.

70 Li L, Chapman K, Hu X, Wong A, Pasdar M. Modulation of the oncogenic potentia of beta-catenin by the subcellular distribution of plakoglobin. Mol Carcinog 2007; 46: 824-838.

71 Winn RA, Bremnes RM, Bemis L, Franklin WA, Miller YE, Cool C et al. gammaCatenin expression is reduced or absent in a subset of human lung cancers and re-expression inhibits transformed cell growth. Oncogene 2002; 21: 7497-7506.

72 Franzen CA, Todorovic V, Desai BV, Mirzoeva S, Yang XJ, Green KJ et al. The desmosomal armadillo protein plakoglobin regulates prostate cancer cell adhesion and motility through vitronectin-dependent Src signaling. PLoS One 2012; 7: e42132.

73 Rieger-Christ KM, Ng L, Hanley RS, Durrani O, Ma H, Yee AS et al. Restoration of plakoglobin expression in bladder carcinoma cell lines suppresses cell migration and tumorigenic potential. Br J Cancer 2005; 92: 2153-2159.

74 Yin T, Getsios S, Caldelari R, Kowalczyk AP, Muller EJ, Jones JC et al. Plakoglobin suppresses keratinocyte motility through both cell-cell adhesion-dependent and -independent mechanisms. Proc Natl Acad Sci USA 2005; 102: 5420-5425.

75 Taelman VF, Dobrowolski R, Plouhinec JL, Fuentealba LC, Vorwald PP, Gumper I et al. Wnt signaling requires sequestration of glycogen synthase kinase 3 inside multivesicular endosomes. Cell 2010; 143: 1136-1148.

76 MacAulay K, Doble BW, Patel S, Hansotia T, Sinclair EM, Drucker DJ et al. Glycogen synthase kinase 3alpha-specific regulation of murine hepatic glycogen metabolism. Cell Metab 2007; 6: 329-337.

77 Patel S, Doble BW, MacAulay K, Sinclair EM, Drucker DJ, Woodgett JR. Tissue-specific role of glycogen synthase kinase 3 beta in glucose homeostasis and insulin action. Mol Cell Biol 2008; 28: 6314-6328.

78 Harada N, Tamai Y, Ishikawa T, Sauer B, Takaku K, Oshima M et al. Intestinal polyposis in mice with a dominant stable mutation of the beta-catenin gene. EMBO J 1999; 18: 5931-5942.

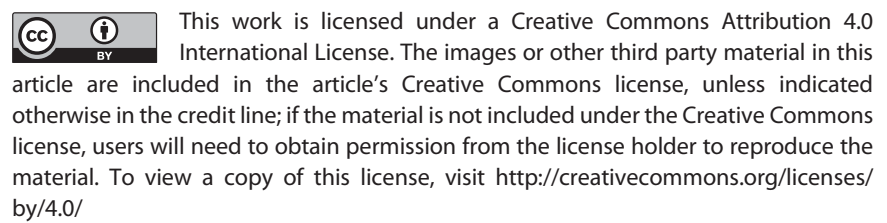
by/4.0/

Supplementary Information accompanies this paper on the Oncogene website (http://www.nature.com/onc) 